\title{
Reel Döviz Kuru Şoklarının İhracat ve D1ş Ticaret Dengesi Üzerindeki Asimetrik Etkileri: Türkiye İçin NARDL Yaklaşımından Kanıtlar
}

\author{
Aslı GÜLER ${ }^{1}$
}

\section{$\ddot{O} z$}

Bu çalıșmanın amacı, Türkiye'de 2013:01-2020:05 döneminde reel efektif döviz kuru ve seçilmiș makroekonomik göstergelerin ihracat ve diş ticaret dengesi üzerinde meydana getirdiği asimetrik kısa ve uzun dönem etkilerini NARDL yaklaşımı ile analiz etmektir. Elde edilen bulgulara göre, pozitif reel kur şokları (TL'nin reel değer kazancı) çok kısa dönemde ihracatı bir derece arttırmakta, ilerleyen dönemlerde ise azaltmaktadır. Negatif reel kur şokları (TL'nin reel değer kaybı) ise ihracatı kademeli bir şekilde arttırmaktadır. Ara malı ithalatı ve AB gelir düzeyi ile ihracat arasında doğru yönlü asimetrik bir ilişki söz konusudur. Ara malı ithalatı ihracatın güçlü bir asimetrik belirleyicisi iken, $\mathrm{AB}$ büyüme oranı zayıf bir belirleyicidir. Diğer taraftan, pozitif reel kur şoku dış ticaret dengesinin ilk üç ayda iyileşmesine sonra ise bozulmasına yol açarken, negatif reel kur şoku dış ticaret dengesinde kademeli bir iyileşmeye yol açmaktadır. Bununla birlikte, uzun dönemde dış ticaret dengesinin TL'nin değer kayıplarına gösterdiği tepki, TL'nin değer kazancına gösterdiği tepkinin iki katıdır. Ayrıca, dış ticaret dengesi ile sanayi üretim endeksi arasında ters yönlü simetrik bir ilişski söz konusu iken diș ticaret hadleri ile pozitif yönlü asimetrik ilișkilidir. Ancak, dıș ticaret hadlerinin Türkiye aleyhine değişmesi durumunda dış ticaret dengenin gösterdiği reaksiyon, hadlerin Türkiye lehine değişmesi durumunda gösterdiği reaksiyondan daha fazladır. AB büyüme oranı ise dış ticaret hadlerinin zayıf bir belirleyicisidir.

Anabtar Kelimeler: Reel Döviz Kuru, İhracat, Dış Ticaret Dengesi, Asimetrik Eşbütünleşme Testi, NARDL Modeli

Asymmetric Effects of Real Exchange Rate Shocks on Exports and Trade Balance: Evidence from NARDL Approach for Turkey

\begin{abstract}
This paper aims to analyze the short and long-term asymmetric and non-linear effects of the real effective exchange rate and selected macroeconomic indicators on exports and foreign trade balance using the nonlinear auto-regressive distributed lag model (NARDL) by monthly data covering 2013:01-2020:05 period for Turkey. According to the findings, positive real exchange rate shocks (real appreciation of TL) lead exports to increase to some extent in a very short period and to decrease in the following periods. On the other hand, negative real exchange rate shocks (real depreciation of TL) cause exports to increase gradually. Furthermore, there are an asymmetrical relationship between exports intermediate goods imports and EU income level with exports. As for the foreign trade balance, the findings are as follows: positive real exchange rate shock (TL appreciation) causes an improvement in the first three months and then a breakdown in the trade balance, while negative real exchange rate shock (real depreciation of TL) leads a gradual improvement in the foreign trade balance. However, it is evidenced that the reaction of the foreign trade balance to the depreciation of the TL in the long term is twice stronger than the reaction to the appreciation of the TL. In addition, while there is a negative directional symmetrical relationship between foreign trade balance and industrial production index, there is a positive directional asymmetric relationship with terms of trade. Nevertheless, the reaction of the foreign trade balance towards a change in the terms of trade against Turkey is more than the reaction to the case of a change in favor. The EU growth rate is a weak determiner of the trade balance.
\end{abstract}

Key Words: Real Exchange Rate, Export, Foreign Trade Balance, Asymmetric Cointegration Test, NARDL Model

Atıf İçin / Please Cite As:

Güler, A. (2021). Reel döviz kuru şoklarının ihracat ve dış ticaret dengesi üzerindeki asimetrik etkileri: Türkiye için NARDL yaklaşımından kanıtlar. Manas Sosyal Araștırmalar Dergisi, 10(2), 950-970.

Geliş Tarihi / Received Date: 27.01.2021

Kabul Tarihi / Accepted Date: 01.04.2021

\footnotetext{
${ }^{1}$ Dr. Öğr. Üyesi - Ordu Üniversitesi İktisadi ve İdari Bilimler Fakültesi, asliguler@odu.edu.tr 


\section{Giriş}

Bretton Woods sisteminin yıkılmasının ardından ulusal paralar birbirleri karşısında dalgalanmaya bırakılarak serbest dalgalanma sistemine geçilmiştir. $O$ dönemde üzerinde anlaşılmış ortak bir parasal sisteme dair bir hazırlık olmadığı için serbest dalgalanma ülkeler için bir tercih değil, daha çok bir mecburiyetti. Ancak, zaman geçtikçe ülkelerin dalgalı kur sisteminden fazla şikâyetçi olmadıkları anlaşılmış ve böylelikle sabit kur sistemi tarihteki yerini büyük ölçüde dalgalı kur sistemlerine bırakmıştır (Seyidoğlu, 2013, s. 41).

Tamamen serbest dalgalı döviz kuru sistemlerinde esas olarak kurlar piyasadaki arz ve talep koşullarına göre değişmekte ve döviz piyasasına neredeyse hiç müdahale edilmemektedir. Ancak, kurların tamamen serbest bırakılması bir takım sorunları da beraberinde getirdiğinden, günümüzde sanayileşmiş ülkeler dışında serbest dalgalanmaya rastlanmamaktadır. Daha ziyade, ülkeler, istikrar bozucu spekülasyonların önüne geçmek, döviz kurunda meydana gelen ekonomik temellerden kopuk dalgalanmaları azaltmak ya da diş ticarete yön vermek gibi amaçlarla zaman zaman döviz piyasasına müdahale etmektedirler.

Dış ticaret dengesini etkilemeye yönelik döviz piyasası müdahaleleri reel döviz kurunun değiştirilmesine odaklıdır. Reel döviz kurunun dış ticaret politikasının bir aracı olarak kullanılmasının dayandığ rasyonalite, reel kurların nispi fiyatların önemli bir bileşeni ve dış rekabet gücünün önemli bir belirleyicisi olmasıdır ${ }^{2}$ (Yllmaz ve Kaya, 2007, s. 70). Şöyle ki, reel döviz kurunun yükselmesi, yani yerli paranın yabancı para karşısında reel değer kaybına uğraması durumunda yerli malların yabancı mallar cinsinden fiyatı ucuzlamakta ve ihracatta rekabet avantajı elde edilmektedir. İthalat açısından ise yerli paranın reel değer kaybı caydırıcı bir nitelik taşımaktadır. Nihayetinde, ihracattaki artışa ve ithalattaki azalmaya bağlı olarak dış ticaret dengesinde bir iyileşme öngörülmektedir. Diğer taraftan, reel döviz kurunun düşmesi, yani yerli paranın reel değer kazancı ise dış ticaret dengesi bakımından tersi bir beklentiye neden olmaktadır. Çünkü bu durumda, yerli malların yabancı mallar cinsinden fiyatı arttı̆ğndan dış rekabet gücünün düşmesi dolayısı ile ihracat hacminin daralması beklenmektedir. Öte yandan, yabanc1 malların daha ucuz hale gelmesi ile ithalat da özendirilmiş olmaktadır. Sonuç olarak ise yerli paranın reel değer kazancının dış ticaret dengesinde bozulmaya yol açacağı öngörülmektedir.

Bununla birlikte, reel kurdaki değişimlerin ihracat ithalat ve dış ticaret dengesi üzerindeki etkileri bir takım yapısal unsurlara bağlı olarak değişebilmekte ve hatta yaşanan krizler ve ekonomik yapının değişmesi nedeni ile ortaya çıkan kırılmalar bu ilişkileri dönüştürebilmektedir. Burada söylenmek istenen, söz konusu makroekonomik değişkenler arasındaki ilişkinin belli bir dönem boyunca doğrusal ve simetrik olmayabileceğidir. Bu konu ile ilgili yaklaşımlar, ilişkilerdeki bu asimetri ve doğrusal olmayışlı̆̆ bazı unsurlara atıfta bulunarak açıklamaktadır. Bunlar, döviz kurundaki değişimlerin ihraç ve ithal mallarının fiyatlarına ne ölçüde yansıtılabileceğini belirleyen fiyat esneklikleri, fiyatların esnek bir şekilde ayarlanmasına izin vermeyen aksak piyasa yapısı, belirli bir dönem için bağlayıcı olan ve fiyatların güncellenmesine izin vermeyen sözleşmeler ve ithal girdi bağımlılığının derecesi gibi sıralanabilir.

Bu yaklaşımların pek çoğunun merkezinde ikiz kavramlar olan Marshall-Lerner (M-L) koşulu ve J eğrisi hipotezi yer almaktadır. Marshall-Lerner ((Marshall (1923), Lerner (1944)) koşulu, reel kur değişimlerinin, diş ticaret dengesi üzerinde meydana getirdiği nihai etkinin ithal ve ihraç mal talebi fiyat esnekliklerinin toplamına bağlı olduğunu ileri sürmektedir. Bu koşula göre, devalüasyonun (sabit kur sisteminde ulusal paranın reel değer kaybının) dış ticaret dengesini iyileştirmesi, ihraç malının yurt dışı fiyat esnekliği ve ithal malının yurt içi fiyat esnekliği toplamı birden büyükse mümkündür. Aksine, eğer esneklikler toplamı birden küçükse, devalüasyon diş ticaret dengesini olumsuz yönde etkileyecek, fiyat esneklikleri toplamının bire eşit olması durumunda ise dış dengede bir değişiklik meydana gelmeyecektir. Bu yaklaşımın savunucularına göre, M-L koşulu dış ticaret dengesinin iyileştirilmesinde gerekli ve yeterli koşulları sağlamaktadır. Ancak, M-L koşulunun sağlanmış olmasına rağmen bazı durumlarda dış ticaret dengesinin bozulmaya devam ettiği durumlar peyda olunca, çalısmaların odak noktası kayarak devalüasyon sonrası diş ticaret dengesinin ayarlanma sürecini gösteren kısa dönem dinamikleri açıklamaya yönelmiş ve J-Eğrisi hipotezi ortaya atılmıştır.

\footnotetext{
2 Doğrudan kotasyon yöntemine hesaplandığında reel kurdaki artış yerli paranın reel değer kaybına uğradığı ve dış rekabet gücünün arttığ1 şeklinde yorumlanırken, reel kurların dolaylı kotasyon yöntemine göre hesaplandığı durumda reel kur artış1, yerli paranın reel değer kazancına ve dış rekabet gücünün aşınmasına yorulur.
} 


\section{GÜLER}

J-Eğrisi hipotezi, devalüasyonun dış ticaret dengesinin kısa vadede bozulmasına, uzun vadede ise iyileşmesine yol açacağını ileri sürerek reel döviz kuru ile dış ticaret dengesi arasındaki ilişkinin dinamik olarak ayarlanan bir süreç olduğuna dikkat çekmektedir. Buna göre, reel döviz kuru değiştiğinde diş ticaret dengesi üzerinde fiyat etkisi hemen ortaya çıkmakta, buna karşın hacim etkisi belli bir gecikme ile kendini göstermektedir. Çünkü ulusal para cinsinden fiyatlar, döviz kurlarındaki değişim ile anında ayarlanırken, tüketicilerin ve üreticilerin göreli fiyatlardaki değişikliklere uyum sağlamak için harcadıkları sürede gecikme yaşanır. Böylece, reel döviz kuru yükseldiğinde (yerli para reel değer kaybına uğradığında), ihraç malları hemen ucuzlarken, ithal mallarının ulusal para cinsinden fiyatları ise yükselir. Buna karşın, diş ticarette yapılmış sözleşmeler nedeni ile ihraç mallarının fiyatlarındaki düşüşe karşılık yeni siparişlerin verilmesi zaman alır. Dolayısı ile kısa dönemde ihracat hacmi artmaz ve ithalat hacmi de azalmaz. Sonuç olarak, dış ticaret hacmi değişmez ve reel kur artışı kısa dönemde dış ticaret dengesinde bozulmaya neden olur. Ancak, belli bir zaman sonra yeni satın alma kararları ile ithalat ve ihracat hacmi yeni reel kura göre ayarlanır. Böylece, ihraç mallarının ucuzlaması ile ihraç malı talebi artar, ithal mallarının pahalı hale gelmesi ile de ithal mal talebi azalır. Nihayetinde, dış ticaret dengesi iyileşir (Bahmani-Oskooee ve Ratha, 2004, s. 1377).

Magee (1973), reel döviz kuru artışı (ulusal paranın değer kaybı) sonrası, kısa dönemde dış ticaret dengesinin bozulmasını, uzun dönemde ise iyileşmesini kısa ve uzun dönem esneklik farklarına bağlamaktadır. Ona göre, kısa dönem esneklikler genellikle uzun dönem esnekliklerden daha küçük olduğundan dış ticaret hacmi kısa dönemde kur değişimlerine yeterli reaksiyonu gösterememektedir. Bu yüzden Magee'e göre (1973) reel değer kaybı sonrası dış ticaret dengesinin kısa dönemde izleyeceği yol teorik olarak belirsizdir.

BRM modeli ise (Bickerdike, 1920, Robinson, 1947; Metzler, 1948), reel döviz kuru değiştiğinde dış ticaret dengesinin arz ve talep esnekliklerine bağlı olarak yeni dengeye uyum sağladığını varsaymaktadır. BRM modelinde, reel döviz kurundaki değişimlerin ihracat ve ithalat piyasası üzerindeki etkileri ayrı ayrı ele alınır. Her bir piyasada arz ve talep sadece ihracatçı ya da ithalatçı ülkenin kendi para birimi cinsinden nominal fiyatların bir fonksiyonudur. Modele göre, devalüasyon sonucu yerli para değer kaybettiğinde ithalat azalmakta ihracat ise artmaktadır. Buna rağmen, devalüasyonun diş ticaret dengesi üzerindeki etkisi belirsizdir. Çünkü devalüasyon sonucu ihracat değeri yükselirken, ithalat değeri talep esnekliğine bağlı olarak düşebilir veya yükselebilir (Dornbusch, 1975, s. 859-861).

Bussiere (2013) ise reel döviz kuru ile diş ticaret dengesi arasındaki ilişkinin simetrik ve doğrusal olmayışlğı̆nın, ayarlanma maliyetlerine, fiyat katılıklarına ve miktar kısıtlamalarına atfedilebileceğini ileri sürmektedir. Ona göre, ulusal paranın değer kaybetmesi ihraç mallarını yabancı para birimi cinsinden daha ucuz ve daha rekabetçi hale getirmektedir. İhraç mallarının ulusal para birimi cinsinden değişmediği ve arz tarafinda bir sıkıntı olmadığı varsayımı altında, bu durumun, ihracatçıların daha fazla ihracat yapmasını ve daha fazla kazanmasını sağlayacağı açıktır. Ancak, sektör hali hazırda tam kapasitede çalıșıyor ve daha yüksek üretim kapasitesine uyarlanmak çok maliyetli ise ihracatçlar ihracat miktarlarını arttırmak yerine fiyatlarını yükseltmeyi daha optimal bulabilirler. Öte yandan, fiyatların yükseltilmesi noktasında sahip olunan bu esneklik, fiyatların düşürülmesi gerektiğinde aynı ölçüde devam etmeyebilir. Şöyle ki, ulusal paranın değer kazanması ihracat mallarını yabancı para cinsinden daha pahalı ve daha az rekabetçi hale getirir. Bu duruma karşlık, dış rekabet gücünün sürdürülebilmesi için ihracatçıların ulusal para cinsinden fiyatlarını ulusal paradaki reel değerlenme ölçüsünde düşürmeleri gerekir. Aksi halde, ihracatçlar daha az ihracat yaparak daha az kazanacaklardır. Ancak, ulusal parada meydana gelen değerlenme çok fazla ise ihracat fiyatlarının bu denli düşürülmesi kar marjlarının da düşmesi anlamına geldiğinden, bir noktadan sonra fiyatları düşürmek gerçekten zorlaşabilir. Fiyatlarda aşağı yönlü bir katıllk anlamına gelen bu durum, dış ticaret dengesinin ulusal paranın değer kazancına gösterdiği reaksiyonun değer kaybına gösterdiği reaksiyondan daha az olması gibi bir sonuç doğurur (Arize, Malindretos ve Igwe, 2017, s. 321).

Reel döviz kuru ile dış ticaret dengesi arasındaki bu etkileşimler, uluslararası piyasalarda rekabet avantajı elde etmek ve dış ticaret dengesini iyileştirmek amacıyla reel döviz kurunun politika aracı olarak kullanılması yönünde güçlü bir motivasyon oluşturmaktadır. Şüphesiz, geçmişten günümüze, pek çok ülkede uygulanan kur rejimine bağlı olarak gerçekleştirilen pek çok devalüasyon, depresiasyonların gerekçelerinden biri de budur (Eryüzlü ve Ekici, 2020, s. 99; Gül ve Ekinci, 2006, s. 165). Türkiye de kronik dış ticaret dengesizliği ile süregelen mücadelesinde zaman zaman reel kur ayarlamalarını politika 
aracı olarak kullanmıştır ${ }^{3}$. Dış ticaret dengesini iyileştirmek adına TL'nin reel değer kaybı sonrası ihracatta bir artış gerçekleşmiş, ancak bu artış kısa dönemli olmasının yanında, ihracat artışı ithalat artışını tetikleyerek dış ticaret açığındaki artışların devam etmesine yol açmıştır (Hepaktan, Çınar ve Dündar, 2011, s. 68). Günümüzde ise Türkiye Cumhuriyet Merkez Bankası'nın (TCMB) nominal ya da reel bir kur hedefi bulunmamaktadır ${ }^{4}$. Bununla birlikte, döviz arz ve talebindeki hareketler ve dönem dönem yaşanan siyasi ve ekonomik gelişmeler kurlarda olağan üstü hareketlere yol açarak makroekonomik dengeleri bozabilmekte ve döviz piyasasına müdahale gerektirebilmektedir ${ }^{5}$. Dış ticaret dengesi bağlamında düşünüldüğünde, reel döviz kurunun ihracat ve diş ticaret dengesi üzerinde meydana getirdiği etkilerin bilinmesi, müdahale politikalarının uygunluğu ve müdahalelerin isabet derecesi açısından oldukça önemlidir.

Bu bağlamda, çalışmanın amacı Türkiye'de ciddi kur hareketliliklerinin yaşandığı 2013:01-2020:05 döneminde, reel döviz kuru ve seçilmiş makroekonomik değişkenler ile ihracat ve diş ticaret dengesi arasındaki dinamik etkileşimi kısa ve uzun dönem ilişkilerde asimetriye izin veren NARDL yaklaşımı ile analiz etmektir. Çalışmanın geri kalanında, önce konu ile ilgili daha önce yapılmış çalışmaların bulguları özetlenmiş, daha sonra çalışmanın veri seti ve metodolojisi tanıtılmıştır. Son olarak ise ampirik analizden elde edilen bulgular değerlendirilmiş ve sonuçlar sunulmuştur.

\section{Literatür}

Literatürde reel döviz kuru ile ihracat ve dış ticaret dengesi arasındaki ilişkiyi ele alan pek çok çalışma mevcuttur. Ancak, söz konusu çalışmaların ele alınan ülke, dönem ya da yöntem farklılıklarına bağlı olduğu düşünülen farklı sonuçlar ürettikleri göze çarpmaktadır. Bu bağlamda, bazı çalışmalar reel döviz kuru ile dış ticaret dengesi arasında anlamlı bir ilişkinin var olduğu yönünde sonuçlar sunarken, bazılarının reel döviz kuru ile dış ticaret arasında ne kısa ne uzun dönemde anlamlı bir ilişki olmadığı şeklinde sonuçlara ulaştıkları görülmektedir. Çalışmanın bu kısmında, daha önce konu ile ilgili yapılış̧ çalışmaların bulguları özetlenmiştir. Çalışmada elde edilen bulgular ile karşılaştırılabilmesi bakımından Türkiye için yapılan çalışmalara ağırlık verilmiştir.

Ayhan (2019), 2005:01-2014:02 dönemine ait aylık veriler ile reel döviz kurunun ihracat üzerindeki etkisini ARDL yaklaşımını kullanarak Türkiye için araştırmıştır. Çalışmanın öne çıkan bulgularına göre, TL'nin değer kazancı ihracat üzerinde kısa ve uzun dönemde olumsuz bir etki meydana getirmektedir. Buna göre, TL reel olarak \%1 değer kaybettiğinde uzun dönemde ihracat $\% 0.19$ oranında azalmaktadır. Ulaşılan diğer sonuçlara göre, yabancı ülkelerin gelirlerinde meydana gelen artış, hem kısa hem de uzun dönemde Türkiye'nin ihracatını pozitif yönde etkilerken, reel kur oynaklığı ise negatif yönde etkilemektedir.

Barak ve Naimoğlu (2018) Türkiye, Arjantin, Pakistan, Mısır ve Katar'dan oluşan ülke grubu için 2000-2014 dönemine ait yıllık veriler ile Panel ARDL, Granger nedensellik testi ve varyans ayrıştırma analiz yöntemlerini kullanarak reel döviz kuru ve ticaret hacmi arasındaki kısa ve uzun dönemli ilişkileri araştırmışlardır. Yapılan analizler neticesinde reel döviz kuru ile dış ticaret hacmi arasında hem kısa hem de uzun dönemde negatif ve anlamlı bir ilişki tespit edilmiştir. PMG tahmincisi ile yapılan hesaplamalara göre reel döviz kurundaki \%1'lik artış uzun dönemde ticaret hacminde \%0.34'lük bir daralma meydana getirmektedir. Diğer taraftan, Granger nedensellik testi sonucunda reel döviz kurundan diş ticaret hacmine doğru anlamlı bir nedensellik tespit edilememiştir.

Kılıç, Özbek ve Çiftçi (2018) çalışmalarında 1990-2015 dönemi için yıllık, 1998:q1-2016:q3 dönemi için ise üç aylık verileri kullanarak ARDL metodu ile reel döviz kuru ve dış denge arasındaki kısa ve uzun dönemli ilişkileri araştırmışlardır. Yıllık veriler ile gerçekleştirilen analizlerde hem kısa hem de uzun

\footnotetext{
${ }^{3}$ Bkz.7 Eylül 1946 Kararları (Türk Lira’sında yaklaşık \%40 değer kaybı), 4 Ağustos 1958 İktisadi İstikrar Tedbirleri ( Türk Lira'sında \%220 değer kaybı), 10 Ağustos 1970 (Türk Lira'sında \%66 değer kaybı), 24 Ocak 1980 Kararları (Türk Lira'sında \%33 değer kaybı), 1995 yılı (Türk Lira'sında \%13 değer kaybı).

4 TCMB, 2021 Para ve Kur Politikası Raporu Madde 78 "Dalgalı döviz kuru rejimi devam edecek, kurlar serbest piyasa koşullarında arz ve talep dengesine göre oluşacaktır. TCMB'nin nominal ya da reel bir kur hedefi bulunmamaktadır. TCMB kurların düzeyini ya da yönünü belirleme amaçlı döviz alım ya da satım işlemi yapmayacaktır. Döviz arz ve talebini belirleyen temel unsurlar uygulanan para ve maliye politikaları, cari denge ve sermaye hareketleri ile ekonomik güven ve beklentilerdir. Öte yandan, döviz piyasasının sağlıklı çalışması amacıyla döviz arz ve talep gelişmeleri yakından takip edilecektir. TCMB kurlarda ekonomik temellerden kopuk aşırı dalgalanma görüldügünde alış ya da satıs yönünde müdahalelerde bulunabilecektir”"

5“ .....TCMB, geçmişte olduğu gibi döviz piyasasının sağlıklı çalışması ve döviz likiditesinin dengelenmesi amacıyla, döviz arz ve talep gelişmelerini yakından takip ederek gerekli önlemleri almaya devam edecektir (TCMB, 2019).
} 


\section{GÜLER}

dönemde TL'deki değer kayıplarının dış dengeyi iyileştirdiği tespit edilirken, çeyrek dönemlik verilerle yapılan analizde ise TL'deki değer kayıplarının kısa dönemde dış dengeyi kötüleştirdiği, uzun dönemde ise dış dengede iyileşme meydana getirdiği tespit edilmiştir. Çalışmanın bir diğer bulgusu, reel döviz kuru şokunun dış denge üzerindeki etkisinin yaklaşık 10 ay içinde ortadan kalkacağı yönündedir. Çeyrek dönemlik veriler üzerinden yapılan hesaplamalara göre, reel döviz kurunda meydana gelen \%1’lik değer kaybı uzun dönemde dış ticaret dengesini yaklaşı $\% 0.70$ oranında iyileştirmektedir.

Arize, Malindretos ve Igwe (2017) Çin, İsrail, Kore, Malezya, Pakistan, Filipinler, Singapur için 1980:01-2013:04, Rusya için ise 1994:q1-2013:q4 dönemine ait verileri ile reel efektif döviz kurunun ticaret dengesi üzerinde meydana getirdiği kısa ve uzun dönem asimetrik etkileri NARDL metodunu kullanarak incelemişlerdir. Gerçekleştirilen asimetrik eşbütünleşme testi sonucunda her ülkede ticaret dengesi ile reel efektif döviz kuru arasındaki istatistiksel olarak anlamlı uzun vadeli ilişki olduğu tespit edilmiştir. Ayrıca, reel döviz kurunun kısa vadede de ticaret dengesi üzerinde bir etkisi vardır. Tüm ülkeler için varılan ortak sonuç ise şu şekildedir: Ulusal para birimlerinde gerçekleşen reel değer kayıpları ticaret dengesini olumlu yönde etkilemektedir. Diğer önemli bir bulgu ise ticaret dengesinin reel değer kayıplarına, reel değer kazançlarından daha fazla reaksiyon gösterdiğidir. Ülkelerin pek çoğunda anlamlı kısa ve uzun dönem asimetrik etkiler tespit edilmiştir.

Petek ve Çelik (2017) çalışmalarında 1990q1-2015q12 dönemine ait veriler ile Türkiye'de, TÜFE, reel efektif döviz kuru, ihracat ve ithalat arasındaki ilişkileri araştırmışlardır. Johansen eşbütünleşme testi sonucuna göre, reel döviz kuru, TÜFE, ihracat ve ithalat değişkenlerinin uzun dönemde ilişkili oldukları tespit edilmiştir. Granger nedensellik testi sonuçlarına göre ise reel döviz kurundan ihracata doğru bir nedensellik ilişkisi tespit edilmiştir. Etki tepki fonksiyonlarına göre, reel döviz kurunda meydana gelen bir birimlik şoka karşı (TL'nin değer kazancı) ihracat negatif yönde tepki vermektedir.

Sönmezler, Akduğan ve Gündüz (2017) 2003:01-2015:10 dönemine ait aylik veriler üzerinden Johansen eşbütünleşme ve Granger nedensellik testlerini kullanarak reel döviz kuru ile aramalı ihracatı, tüketim malı ihracatı ve toplam ihracat arasındaki ilişkileri araştırmışlardır. Eşbütünleşme testi sonucunda ilgili değişkenlerin uzun dönemde birlikte hareket ettikleri sonucuna ulaşılmıştır. Diğer yandan, elde edilen diğer bir bulgu ise ithalatın reel kurlardaki değişime olan duyarlılığının ihracatınkine oranla daha yüksek olduğudur.

Eichengreen ve Gupta (2013) 1980-2009 yıllarını kapsayan dönem için farklı gelişmişlik düzeyindeki 60 ülkeye ait veriler üzerinden reel döviz kurunun mal ve hizmet ihracatı üzerindeki etkisini panel regresyon analizi ile incelemişlerdir. Çalışmada, reel döviz kuru hem logaritmik düzey formunda hem de yüzde değişim olarak regresyonlarda kullanılmıştır. Elde edilen bulgular, reel döviz kurunun ihracat artışı için önemli olduğunu doğrulamıştır. Bunun da ötesinde, reel döviz kurunun hizmet ihracatı üzerinde mal ihracatına göre daha güçlü etkiler bıraktığı görülmüştür. Diğer taraftan, reel döviz kurunun ihracat üzerindeki etkisinin ülkelerin gelişmişlik düzeyine göre farklılaştığına dair güçlü bir kanıt elde edilememiştir. Ayrıca, gelişmekte olan ülkeler için emtia ve ticari mal ihracatından geleneksel ve modern hizmet ihracatına geçildikçe, reel döviz kuruna yönelik politikaların daha önemli hale geleceği ileri sürülmüştür.

Aktaş (2010) 1989:q1-2008:q4 dönemine ait üç aylık veriler üzerinden gerçekleştirdikleri VAR analizi neticesinde reel kurdaki değişikliklerin ticaret dengesi üzerinde anlamlı bir etki meydana getirmediği anlaşılmıştır. Buna göre, reel döviz kurunun dış ticaret dengesini daha iyi hale getirmek için etkin bir politika aracı olarak kullanılamayacağı ileri sürülmüștür.

Yılmaz ve Kaya (2007) çalışmalarında reel döviz kuru, ihracat ve ithalat arasındaki ilişkileri, 1990:12004:6 dönemine ait veriler ile VAR modeli kullanarak araştırmışardır. Elde edilen bulgulara göre, ithalat ve ihracat arasında çift yönlü bir nedensellik ilişkisi söz konusudur. Ayrıca, reel kurda meydana gelen değişimler diş ticaret dengesi üzerinde anlamlı bir etki oluşturmamaktadır. Buna göre, çalışmada varılan sonuç, reel döviz kurunun etkin bir dış ticaret politikası aracı olarak kullanılamayacağı yönündedir. Diğer taraftan, ithalat ve ihracat arasındaki kuvvetli bağ nedeni ile ithalatın kısıtlanması durumunda ihracatın da olumsuz etkileneceği ileri sürülmüştür.

Gül ve Ekinci (2006) reel döviz kuru, ihracat ve ithalat arasındaki kısa ve uzun dönemli ilisskileri 1990:01-2006:08 dönemine ait aylik verileri kullanarak Granger nedensellik ve Johansen eşbütünleşme testleri ile analiz etmişlerdir. Elde edilen bulgulara göre, seriler arasında uzun dönemde eşbütünleşme 
ilişkisi söz konusudur. Diğer yandan, nedensellik testi sonucuna göre, reel döviz kurundan ne ithalat ne de ihracata doğru bir nedensellik ilişkisi tespit edilememiştir.

Barışı ve Demircioğlu (2006) Türkiye'de 1980:01-1989:03, 1989:04-1999:12 dönemlerinde reel döviz kuru, ithalat ve ihracat arasındaki kısa ve uzun dönemli ilişkileri Johansen eşbütünleşme, Granger nedensellik ve parçalı regresyon analizlerini kullanarak araştırmışlardır. Çalışmada, reel kur değişimleri ile ihracat ve ithalat değişimleri arasında 1980-2001 dönemini kapsayan uzun dönemli bir ilişki saptanmıştır. Buna ek olarak, reel döviz kurundan ithalat ve ihracata doğru güçlü bir nedensellik ilişkisi bulunmuş, ancak reel kurun ihracat üzerindeki etkisinin ithalat üzerindeki etkisinden daha zayıf olduğu tespit edilmiştir.

Yamak ve Korkmaz (2005) Türkiye'de reel döviz kuru ile dış ticaret arasındaki ilişkileri farklı mal gruplar1 üzerinden 1995:1-2004:4 dönemine ait veri setini kullanarak Granger nedensellik analizi ve EtkiTepki fonksiyonları aracilığı inceledikleri çalısmalarında şu sonuçlara ulaşmışlardır: i) Engle-Granger sürecine göre seriler arasında uzun dönemli hiçbir ilişki yoktur. ii) TL'nin değer kazanması dış ticaret açığını arttırmaktadır. iii) TL'nin değer kazanması, sermaye ve tüketim mallarının dış ticaret dengesini bozarak dış açığın artmasına neden olmaktadır. iv) Dış açığın artması, TL'nin reel olarak değer kaybetmesine yol açmaktadır. TL'nin değer kaybı ise sermaye malları dış açığının küçülmesine yol açarak dış ticaret dengesini olumlu etkilemektedir. Ancak, sermaye malı dış ticaret açığının küçülmesi, ekonomik büyümeyi yavaşlatmaktadır.

Şimşek-Kadılar (2004) çalışmalarında 1970-2002 dönemini kapsayan yıllık veri seti ile ARDL sınır testi yaklaşımını kullanarak Türkiye'nin dış ticaret politikasına ilişkin bazı sonuçlar elde etmişlerdir. Elde edilen veriler ışığında ulaşılan sonuçlar şu şekildedir: İhracatın fiyat esnekliği -1.01 olarak hesaplanmıştır. Buna göre, devalüasyonların dış ticaret dengesizliklerinin iyileştirilmesinde etkin bir şekilde kullanılabileceği ileri sürülmüştür. Diğer taraftan, diş dengesizliklerin giderilmesinde üretim artışının devalüasyonlardan daha etkin kullanılacağı belirtilmiştir.

\section{Veri Seti}

Bu çalışmanın veri seti 2013:01-2020:05 dönemine ait aylık verilerden oluşmaktadır. Konu ile ilgili literatür incelendiğinde, döviz kurunda meydana gelen değişimlerin ihracat ve dış ticaret dengesi üzerindeki etkisinin 12 ay içerisinde ortaya çıkıp kaybolduğu anlaşılmıştır. Bu nedenle analizler, aylık frekanstaki veriler ile yürütülmüștür. NARDL metodunda her bir açıklayıcı değişken pozitif ve negatif bileşenlerine ayrılmakta ve böylelikle kısa ve uzun dönemde pozitif ve negatif şokların bağımlı değişken üzerindeki etkileri ayrı ayrı tahmin edilebilmektedir. Bu çalışmada iki ayrı NARDL modeli kurularak ihracat ve dış ticaret dengesinin reel döviz kuru ve diğer belirleyicilerinde meydana gelen pozitif ve negatif şoklara kısa ve uzun dönemde gösterdikleri asimetrik reaksiyonlar ayrı ayrı incelenmiştir. Modellere dâhil edilen reel döviz kuru dışındaki açıklayıcı değişkenler, teori ve daha önce yapılmış çalışmaların sonuçları göz önünde bulundurularak belirlenmiştir. Bu bağlamda, birinci modelin bağımlı değişkeni olan ihracat, reel döviz kuru, hammadde ve aramalı ithalatı ve yurt dişı gelir seviyesi ile ilişkilendirilmiştir. İkinci modelin bağımlı değişkeni olan diş ticaret dengesi ise reel döviz kuru, yurt içi gelir, yurt dışı gelir ve diş ticaret hadleri ile ilişkilendirilmiştir. Her iki model logaritmik formda oluşturulduğundan elde edilen katsayılar aynı zamanda esneklikleri ifade etmektedir.

Çalışmada kullanılan ihracat serisi, genel ticaret sistemi kapsamında geniş ekonomik grupların sınıflamasına göre elde edilen ABD doları cinsinden ihracat değerleridir. Dış ticaret dengesi serisi ise ihracatın ithalata oranı şeklinde hesaplanmışır. Reel döviz kurunu temsilen kullanılan seri TÜFE bazlı reel efektif döviz kuru endeksidir. Bu seri nominal efektif döviz kurunun TÜFE endeksi ile deflate edilmesi suretiyle hesaplanmaktadır. Türkiye'nin dış ticaretinde önemli paya sahip ülkelerin para birimlerinden oluşan sepete göre, TL'nin ağırlıklı ortalama değerini ifade eden nominal efektif döviz kuru, ülkeler arası nispi fiyat farklarını göstermemektedir. Bu nedenle, TCMB tarafından TL'nin reel düzeyinin göstergesi olarak reel efektif döviz kuru endeksleri hesaplanmaktadır. Bu endeksler, ülkemiz fiyat düzeyinin, dış ticaret yaptı̆̆ımız 44 ülkenin fiyat düzeylerine oranının ağırlıklı geometrik ortalaması alınarak oluşturulmaktadır. Hesaplamalarda kullanılan matematiksel formül aşağıdaki gibidir:

$$
R E K=\prod_{\dot{\mathrm{I}}=1}^{N}\left[\frac{P_{T U R}}{P_{i} * e_{i, T U R}}\right]^{W_{\mathrm{i}}}
$$

Yukarıdaki denklemde $P_{T U R}$ Türkiye'nin fiyat endeksini, $P_{i}$ i ülkesine ait fiyat endeksini, $e_{i, T U R}$, i ülkesinin parası ile TL arasındaki nominal döviz kurunu, $w_{i}$, i ülkesinin reel döviz kuru endeksindeki 


\section{GÜLER}

ağırlığını, N ülke sayısını göstermektedir. TCMB reel kur endeksini hesaplarken dolaylı kotasyon yöntemini kullanmaktadır. Bu nedenle, reel efektif döviz kurundaki artışlar TL'nin reel olarak değer kazandığını, reel efektif döviz kurundaki düşüşler ise TL'nin reel olarak değer kaybettiğini göstermektedir. Bu bağlamda, reel döviz kuru arttığında dış rekabet gücü azalmakta, reel döviz kuru düştüğünde ise dış rekabet gücü artmaktadır.

Türkiye'de kronik hale gelmiş dış ticaret açıklarının temel nedeni ihracatın ithalata olan bağımlılığıdır. $\mathrm{Bu}$ durumun en önemli göstergesi, sektör bazında farklılaşsa da, ortalama olarak ihracat bedelinin \%60'ına ulaşan ithal girdi maliyetleridir. İthalat yapmadan üretimi ve ihracatı sürdürmek neredeyse imkânsızdır. Bu doğrultuda önemli bir belirleyici olduğu düşünülen hammadde ve aramalı ithalat miktar endeksi ihracat modeline açıklayıcı değişken olarak dahil edilmiştir.

İhracat yapılan ülkelerin gelir ve büyüme oranlarına ilişkin gelişmelerin ihracat hacmi ve dış ticaret dengesi üzerinde potansiyel olarak etkili olduğu bilinmektedir. T.C. Ticaret Bakanlığı'nın verilerine göre, en fazla ihracat yapilan ve toplam ihracat hacmi içerisindeki payları \%50 'yi bulan 10 ülkenin yarısını Avrupa Birliği $(\mathrm{AB})$ ülkeleri oluşturmaktadır. Bu ülkelerin toplam ihracat içindeki payı ise $\% 33$ civarındadır. Bu nedenle, çalışmada Avrupa Birliği GSYH büyüme oranı, yurt dışı gelir düzeyini temsilen modellerde kullanılmışır.

Çalışmada kullanılan dış ticaret hadleri endeksi, ihracat birim değer endeksinin ithalat birim değer endeksine bölünmesi sureti ile elde edilmiştir. Dıș ticaret hadleri belli bir baz yıla göre hesaplanmaktadır. Bu nedenle, endeks değerinin 100'ün üzerinde olması, baz yılına göre ihraç mallarını daha pahalıya satıp, ithal mallarını daha ucuza aldığımız anlamına gelirken, endeks değerinin 100'ün altında olması tersi şekilde yorumlanmaktadır. Dış ticaret hadleri ile dış ticaret dengesi arasında doğru yönlü bir ilişkinin ortaya çıkması beklenmektedir.

Ulusal gelir düzeyi toplam talebin önemli bir belirleyicisidir. Ekonominin genişlediği dönemlerde, gelir artısı bir yandan, yurt içinde üretilen mallara yönelik artan talebin artmasına neden olarak ihracatı düşürürken, diğer yandan da ithalatın artmasına neden olmaktadır. Bu iki etkinin toplamı ise dış ticaret dengesinde bozulmaya yol açabilmektedir. Ekonomik daralma dönemlerinde ise gerek yurt içi mallara gerekse ithal mallarına talep azaldığından dış ticaret dengesinde iyileşme gözlenmektedir. Şüphesiz, gelir değiştiğinde dış ticaret dengesi üzerinde meydana gelecek net etki ihraç ve ithal mallarının gelir esnekliklerine bağlıdır. Sanayi üretim endeksi ekonomik genişleme ve daralma dönemlerine ilisskin öncü bir gösterge olması bakımından bu çalışmada yurt içi gelir seviyesini temsilen kullanılmıştır. Değişkenlere ilişkin kısaltmalar ve açıklamalar Tablo 1'de sunulmuştur.

Tablo 1. Değğşkenlere Ait Açılelayıcı Bilgiler

\begin{tabular}{llc}
\hline Değiskenle & Açılama & Kaynak \\
\hline Exp & $\begin{array}{l}\text { İhracat (ABD Doları Cinsinden Genel Ticaret Sistemine Göre Dış Ticaret Geniş Ekonomik } \\
\text { Grupların Sınıflamasına (BEC)) }\end{array}$ & TÜIKK \\
\hline TB & İhracat/İthalat (ABD Doları, Genel Ticaret Sistemi Kapsamında BEC Sınıflamasına Göre) & TÜIK \\
\hline Rex & TÜFE Bazlı Reel Efektif Döviz Kuru (2003=100) & TCMB \\
\hline Imp & İthalat-(Miktar) (Hammadde (ara malları) BEC Sınıflamasına Göre (2010=100)) & TÜIK \\
\hline Growth & Avrupa Birliği GSYİH Büyüme Oranı (Önceki yılın aynı dönemine göre) & FRED \\
\hline Sue & Sanayi Üretim Endeksi (2015=100)(TÜİK) & TCMB \\
\hline Tot & İhracat Birim Değer Endeksi / İthalat Birim Değer Endeksi (BEC Sınıflamasına Göre, 2010=100) & TÜİK \\
\hline
\end{tabular}

\section{Yöntem}

Bu çalsşmada, ihracat ve dış ticaret dengesinin reel döviz kuru ve diğer potansiyel belirleyicileri ile kısa ve uzun dönem asimetrik ilişkilerinin dinamik yapısı Shin, Yu ve Greenwood-Nimmo (2014) tarafindan geliştirilen doğrusal olmayan otoregresif gecikmesi dağıtılmış model (NARDL) kullanılarak analiz edilmiştir. NARDL yaklaşımı Pesaran ve diğerleri (2001) tarafından geliştirilen ARDL modelinin kısa ve uzun dönem asimetrileri içerecek şekilde genişletilmiş halidir. NARDL modeli, küçük örneklemlerde iyi performans göstermesi ve geleneksel eşbütünleşme testlerinin aksine, tüm değişkenlerin aynı dereceden entegre olmasını gerektirmemesi bakımından esnek ve kullanışlı bir çerçeve sunmaktadır. Ancak, daha önemlisi NARDL yaklaşımı gizli eşbütünleşme ilisskisinin yakalanmasına da imkân vermektedir. Granger ve Yoon (2002, s. 27) tarafindan ortaya atılan gizli eşbütünleşme kavramı, geleneksel olarak eşbütünleşik olmayan iki serinin pozitif ve negatif bileşenleri arasındaki eşbütünleşme ilişkisinin varllğına atfen ortaya 
atılmıştır. Gizli eşbütünleşmenin belirlenmesi, dinamik ilişkileri daha iyi anlamamıza ve iyileştirilmiş tahminler üretmemize yardımcı olmaktadır (Shahzad, Nord, Ferrer ve Hammoudeh, 2017, s. 212-215).

NARDL yaklaşımı, uzun dönem eşbütünleşme denklemi ile ilişkili dinamik hata düzeltme modelinden oluşmaktır. Bu yaklaşım, bağımlı ve bağımsız değişkenler arasındaki ilişkilerin yalnızca uzun dönemde asimetrik, yalnızca kısa dönemde asimetrik ya da hem kısa hem de uzun dönemde asimetrik olmasına izin vermektedir. Ayrıca, bu yaklaşım, asimetrik dinamik çarpanlar vasıtasıyla regresörlerde meydana gelen pozitif ve negatif şoklara karşı bağımlı değişkenin verdiği tepkileri dinamik biçimde ölçme imkânı sağlamaktadır (Arize, Malindretos ve Igwe, 2017, s. 318).

Shin ve diğerleri (2014), NARDL yaklaşımını geliştirirken ilk aşamada uzun dönem asimetrik koentegrasyon denklemi ile ilişkili dinamik hata düzeltme modelini oluşturmuşlardır. Daha sonraki aşamada ise Pesaran ve Shin (1998) ve Pesaran ve diğerleri (2001)'i takiben değişkenlerin tamamen I(0), tamamen I(1), ya da değişkenler karş1lıklı eşbütünleşik olduğunda da geçerli bir uzun dönem ilişkinin varlı̆̆1 sınır testi sınanmaktadır. Üçüncü aşamada, Wald testi ile kısa ve uzun dönem asimetrilerin varlı̆g1 test edilmektedir. Son aşamada ise açılayıcı değişkenlerde meydana gelen birim pozitif ve negatif şok sonrası bağımlı değişkenin asimetrik ayarlanma modelini gösteren asimetrik kümülatif dinamik çarpanlar hesaplanmaktadir.

Non-lineer ARDL (p, q) modeli aşağıdaki gibi gösterilmektedir.

$$
y_{t}=\sum_{j=1}^{p} \phi_{j} y_{t-j}+\sum_{j=0}^{q}\left(\theta_{j}^{+\prime} x_{t-j}^{+}+\theta_{j}^{-\prime} x_{t-j}^{-}\right)+\epsilon_{t}
$$

Burada $x_{t} \mathrm{k} \times 1$ açılklayıcı değişkenler vektörünü temsil etmektdir. $x_{t}$ ' de meydana gelen değişimler sıfir eşiği etrafında dağılan pozitif $\left(x_{t}^{+}\right)$ve negatif $\left(x_{t}^{-}\right)$bileşenlerine ayrılmaktadır. ( $x_{t}=x_{0}+x_{t}^{+}+$ $\left.x_{t}^{-}\right) . \phi_{j}$ bağımlı değişkenin kendi gecikmelerine ait parametreleri, $\theta_{j}^{+}$ve $\theta_{j}^{-}$ise asimetrik dağılımlı gecikme parametrelerini, $\epsilon_{t}$ hata terimini ifade etmektedir.

Denklem 2 aşağıdaki gibi dönüştürülmek suretiyle asimetrik hata düzeltme modeli oluşturulmaktadır:

$$
\begin{aligned}
\Delta y_{t} & =p y_{t-1}+\theta^{+\prime} x_{t-1}^{+}+\theta^{-\prime} x_{t-1}^{-}+\sum_{j-1}^{p-1} \gamma_{j} \Delta y_{t-j}+\sum_{j=0}^{q-1}\left(\alpha_{j}^{+\prime} \Delta x_{t-j}^{+}+\alpha_{j}^{-\prime} \Delta x_{t-j}^{-}\right)+\varepsilon_{t} \\
& =p \xi_{t-1}+\sum_{j-1}^{p-1} \gamma_{j} \Delta y_{t-j}+\sum_{j=0}^{q-1}\left(\alpha_{j}^{+\prime} \Delta x_{t-j}^{+}+\alpha_{j}^{-\prime} \Delta x_{t-j}^{-}\right)+\varepsilon_{t}
\end{aligned}
$$

Burada, $\quad p=\sum_{j=1}^{p} \theta_{j}-1, \quad \gamma_{j}=-\sum_{i=j+t}^{p} \theta_{i}, \quad j=1, . ., \mathrm{p}-1, \quad \theta^{+}=\sum_{j=0}^{q} \theta_{j}^{+}, \theta^{-}=\sum_{j=0}^{q} \theta_{j}^{-}$, $\alpha_{0}^{+}=\theta_{0}^{+}, \quad \alpha_{j}^{+}=-\sum_{i=j+1}^{q} \theta_{j}^{+} \quad \mathrm{j}=1, \ldots . . \mathrm{q}-1, \quad \alpha_{0}^{-}=\theta_{0}^{-}, \quad \alpha_{j}^{-}=-\sum_{i=j+1}^{q} \theta_{j}^{-} \quad \mathrm{j}=1, \ldots \ldots \ldots \ldots \mathrm{q}-1$, ve $\xi_{t}=y_{t}-\beta^{+^{\prime}} x_{t}^{+}-\beta^{{ }^{\prime}} x_{t}^{-}$non-lineer hata düzeltme katsayısını temsil etmektedir. $\beta^{+}=-\theta^{+} / p$ ve $\beta^{-}=-\theta^{-} / p$ uzun dönem asimetrik katsayılardır. Açıklayıcı değişkenlerde $\left(x_{t}\right)$ meydana gelen pozitif ve nagatif değişikliklere karşı kısa dönem ayarlanmalar $x_{t}^{+}$ve $x_{t}^{-}$katsayıları tarafindan temsil edilmektedir. NARDL modelinde değişkenler arasında geçerli asimetrik bir eşbütünleşme ilişkisi tespit edildikten sonra Wald testi ile uzun $\left(\theta=\theta^{+}=\theta^{-}\right)$ve kısa dönem $\left(\sum_{i=0}^{q-1} x_{i}^{+}=\sum_{i=0}^{q-1} x_{i}^{-}\right)$asimetri testleri yapılmaktadır. Son aşamada ise açıklayıcı değişkenlerde meydana gelen bir birim pozitif $\left(x_{i}^{+}\right)$ve negatif $\left(x_{i}^{-}\right)$şokun bağımlı değişkende $\left(y_{t}\right)$ meydana getirdiği asimetrik birikimli dinamik çarpan etkisi hesaplanmaktadır.

$$
m_{h}^{+}=\sum_{j=0}^{h} \frac{\partial y_{t-j}}{\partial x_{t}^{+}}, \quad m_{h}^{-}=\sum_{j=0}^{h} \frac{\partial y_{t-j}}{\partial x_{t}^{-}}, \quad h=0,1,2 \ldots . .
$$

$h \rightarrow \infty, m_{h}^{+} \rightarrow \beta^{+}$ve $m_{h}^{-} \rightarrow \beta^{-}, \quad$ Burada $\beta^{+}=-\theta^{+} / p$ ve $\beta^{-}=-\theta^{-} / p$ uzun dönem asimetrik katsayıları temsil etmektedir. Bu çalışmada tahmin edilen NARDL modelleri aşağıdaki 5 ve 6 numaralı denklemlerde gösterildiği gibidir:

$$
\begin{aligned}
& \Delta \operatorname{Exp}_{t}= \\
& \mu+p \operatorname{Exp}_{t-1}+\theta_{1}^{+^{\prime}} \operatorname{Rex}_{t-1}^{+}+\theta_{1}^{-^{\prime}} \operatorname{Rex}_{t-1}^{-}+\theta_{2}^{+^{\prime}} \operatorname{Imp}_{t-1}^{+}+\theta_{2}^{-^{\prime}} \operatorname{Imp}_{t-1}^{-}+\theta_{3}^{+{ }^{\prime}} \operatorname{GrowthEU}_{t-1}^{+}+ \\
& \theta_{3}^{-\prime} \text { GrowthE } U_{t-1}^{-}+\sum_{j-1}^{p-1} \gamma_{j} \Delta \operatorname{Exp}_{t-j}+\sum_{j=0}^{q-1}\left(\alpha_{1 j}^{+\prime} \Delta \operatorname{Rex}_{t-j}^{+}+\alpha_{1 j}^{-1} \Delta \operatorname{Rex}_{t-j}^{-}\right)+\sum_{j=0}^{q-1}\left(\alpha_{2 j}^{+} \Delta \operatorname{Imp} p_{t-j}^{+}+\right. \\
& \left.\alpha_{2 j}^{-1} \Delta \operatorname{Imp} p_{t-j}^{-}\right)+\sum_{j=0}^{q-1}\left(\alpha_{3 j}^{+\prime} \Delta G r o w t h E U_{t-j}^{+}+\alpha_{3 j}^{-1} \Delta \text { GrowthEU } U_{t-j}^{-}\right)+\varepsilon_{t}
\end{aligned}
$$


$\Delta T B_{t}=\mu+p T B_{t-1}+\theta_{1}^{+{ }^{\prime}} \operatorname{Rex}_{t-1}^{+}+\theta_{1}^{{ }^{\prime}} \operatorname{Rex}_{t-1}^{-}+\theta_{2}^{+^{\prime}}$ Sue $_{t-1}^{+}+\theta_{2}^{-{ }^{\prime}}$ Sue $e_{t-1}^{-}+$GrowthE $_{t-1}^{+}+$ $\theta_{3}^{-^{\prime}}$ GrowthEU $U_{t-1}^{-}+\theta_{4}^{+^{\prime}}$ Tot $_{t-1}^{+}+\theta_{3}^{-\prime} \operatorname{Tot}_{t-1}^{-}+\sum_{j-1}^{p-1} \gamma_{j} \Delta T B_{t-j}+\sum_{j=0}^{q-1}\left(\alpha_{1 j}^{+{ }^{\prime}} \Delta \operatorname{Rex}_{t-j}^{+}+\right.$ $\left.\alpha_{1 j}^{-\prime} \Delta \operatorname{Rex}_{t-j}^{-}\right)+\sum_{j=0}^{q-1}\left(\alpha_{2 j}^{+^{\prime}} \Delta \mathrm{Sue}_{t-j}^{+}+\alpha_{2 j}^{-\prime} \Delta S u e_{t-j}^{-}\right)+$ $\sum_{j=0}^{q-1}\left(\alpha_{3 j}^{+^{\prime}} \Delta\right.$ GrowthE $U_{t-j}^{+}+\alpha_{3 j}^{\prime^{\prime}} \Delta$ GrowthEU $\left._{t-j}^{-}\right)+\sum_{j=0}^{q-1}\left(\alpha_{4 j}^{+^{\prime}} \Delta \operatorname{Tot}_{t-j}^{+}+\alpha_{4 j}^{-^{\prime}} \Delta\right.$ Tot $\left._{t-j}^{-}\right)+\varepsilon_{t}$ (6)

\section{Birim Kök Testi}

NARDL yaklaşımı analizde kullanılan değişkenlerin aynı derecede koentegre olması şartını elimine etmektedir. Buna rağmen, bu yöntem değişkenler I(2) olduğunda kullanılamadığından analize geçilmeden önce birim kök testi ile değişkenlerin durağanlık seviyelerinin sorgulanması gerekmektedir. Tablo 2'de serilere ait yapısal kırılmalı birim kök testi sonuçları gösterilmektedir.

Tablo 2. Zivot Andrews Yapısal Kırlmalı Birim Kök Testi Sonucları

\begin{tabular}{|c|c|c|c|c|c|c|c|}
\hline & & Düzey & & & $\mathrm{Fa}$ & & \\
\hline & Model & Test Istatistiği & Kerlma Noktast & $k$ & Test $\dot{I}_{\text {statistiği }}$ & Kerlma Noktast & k \\
\hline \multirow[t]{2}{*}{ Exp } & A & $-3.71 * *$ & $2017: 03$ & 1 & - & - & - \\
\hline & C & $-3.34 * *$ & 2018:09 & 1 & - & - & - \\
\hline \multirow[t]{2}{*}{ TB } & A & $-5.30 *$ & 2018:08 & 0 & - & - & - \\
\hline & $\mathrm{C}$ & $-6.48^{*}$ & 2018:08 & 0 & - & - & - \\
\hline \multirow[t]{2}{*}{$\operatorname{Rex}$} & A & $-3.71 * *$ & 2018:04 & 2 & - & - & - \\
\hline & C & $-3.85^{*}$ & 2018:05 & 2 & - & - & - \\
\hline \multirow[t]{2}{*}{$\operatorname{Imp}$} & A & $-5.53 *$ & 2018:08 & 1 & - & - & - \\
\hline & $\mathrm{C}$ & -5.55 & 2018:08 & 1 & - & - & - \\
\hline \multirow[t]{2}{*}{ GrowthEU } & A & 1.46 & 2019:04 & 0 & $-7.77 *$ & 2019:03 & 0 \\
\hline & $\mathrm{C}$ & $-1.84 * *$ & 2019:04 & 0 & $-9.67 *$ & 2019:03 & 0 \\
\hline \multirow[t]{2}{*}{ Sue } & A & $-7.40 *$ & 2019:01 & 0 & - & - & - \\
\hline & $\mathrm{C}$ & $-8.16 * * *$ & 2017:10 & 0 & - & - & - \\
\hline \multirow[t]{2}{*}{ Tot } & A & $-2.73^{*}$ & 2017:01 & 0 & $-9.86 *$ & 2016:03 & 0 \\
\hline & $\mathrm{C}$ & -2.00 & 2014:10 & 0 & $-9.78 *$ & 2016:03 & 0 \\
\hline
\end{tabular}

Not: Model A, trend durağan alternatif hipotezi altında, trend fonksiyonunun sabit katsayısında bir kırılma olduğunu varsayarken, Model C, sabit ve trendde eşzamanlı bir kırılma olduğunu varsayar. k, Akaike bilgi kriterine (AIC) göre belirlenen uygun gecikme sayısıdır (4 gecikme uzunluğuna göre). *,**,*** sırasıyla $\% 1, \% 5$ ve $\% 10$ 'daki anlamllık düzeylerini ifade eder. Zivot ve Andrews (1992) \% $1 \mathrm{ve} \% 5 \mathrm{ve} \% 10$ anlamlllık düzeylerindeki kritik değerler Model A için sırasıyla 5,34, -4,93 ve -4,58 ve Model C için $5,57,-5,08,-4,82$ 'dir.

Test sonuçlarına göre, yapısal kırılmalar dikkate alındığında dahi tüm değişkenlerin en fazla birinci derecede durağan oldukları görülmektedir. Zaman serilerinin yapısal kırlmalara maruz kalması, değişkenler arasında kısa ve uzun dönem asimetrik ilişkilerin ortaya çıkma olasılığını arttırmaktadır (Shahzad ve diğerleri, 2017:218).

\section{Bulgular}

NARDL yaklaşımında ilk aşamada değişkenler arasında asimetrik bir eşbütünleşme ilişkisinin olup olmadığı asimetrik sınır testi ile test edilmektedir. Tablo 3, değişkenler arasındaki uzun dönemli asimetrik ilişkinin varlığına dair yapılan asimetrik eşbütünleşme testi sonuçlarını göstermektedir. Tablo 3'e göre, ihracat modeli için (Model 1) hesaplanan F istatistiği (17.20), \%1 anlamlllık seviyesindeki üst kritik sınır olan 4.9 değerinin üzerindedir. Dış ticaret dengesi modeli için (Model 2) hesaplanan F istatistiği de (7.82) $\% 1$ anlamlılık seviyesindeki üst kritik değer olan 3.77 değerini aşmaktadır. Bu sonuçlara göre, boş hipotez her iki model için de güçlü bir şekilde reddedilmiş ve değişkenler arasında uzun dönemli asimetrik ve doğrusal olmayan bir ilişkinin varlığ kabul edilmiştir.

Tablo 3. NARDL Modelleri için Sınır Testi Sonuçlar

\begin{tabular}{|c|c|c|c|c|}
\hline & \multicolumn{2}{|l|}{ Model 1} & \multicolumn{2}{|l|}{ Model 2} \\
\hline Optimum Gecikme Uzunluğu & \multicolumn{2}{|c|}{$(1,1,0,0,2,2,3)$} & \multicolumn{2}{|c|}{$(2,2,0,1,2,2,1,1,2)$} \\
\hline $\mathrm{F}$ istatistiği. & \multicolumn{2}{|c|}{$17.20^{*}$} & \multicolumn{2}{|c|}{$7.82 *$} \\
\hline $\mathrm{k}$ & \multicolumn{2}{|l|}{6} & \multicolumn{2}{|l|}{8} \\
\hline Kritik Değerler & Alt Sinit & Üst Sinir & Alt Sinir & Üst Sinit \\
\hline$\% 1$ & 3.6 & 4.9 & 2.62 & 3.77 \\
\hline$\% 5$ & 2.87 & 4 & 2.11 & 3.15 \\
\hline$\% 10$ & 2.53 & 3.59 & 1.85 & 2.85 \\
\hline
\end{tabular}


Not: Model seçiminde uygun gecikme uzunluğu Akaike bilgi kriterine göre genelden özele yaklaşımı ile belirlenmiştir (max p $=$ max q=12). *, \%1 anlamlllık derecesini göstermektedir.

NARDL yaklaşımında değişkenler arasında asimetrik uzun dönemli ilişkinin bulunmasının ardından, açıklayıcı değişkenlerde meydana gelen pozitif ve negatif şokların ihracat ve dış ticaret dengesi üzerindeki etkilerinin kısa ve uzun dönemde asimetrik olup olmadığ Wald Testi ile test edilmektedir. Tablo 4 ve 5 Model 1 ve Model 2 için kısa ve uzun dönem asimetriye ilişkin Wald test sonuçlarını sunmaktadır.

Tablo 4. Model 1 için Kısa ve Uzun Dönem Asimetriye Illiskin Wald Testi Sonuclar

\begin{tabular}{lll}
\hline Değisskenler & Uzun Dönem Asimetri $\left(\mathrm{w}_{\mathrm{LR}}\right)$ & Kisa Dönem Asimetri $\left(\mathrm{w}_{\mathrm{SR}}\right)$ \\
\hline Rer & $9.09^{*}(0.0003)$ & $6.19^{*}(0.003)$ \\
$\mathrm{Imp}$ & $25.64^{*}(0.00)$ & $5.04^{*}(0.009)$ \\
Growth & $2.97^{* *}(0.04)$ & $3.06^{* *}(0.03)$ \\
\hline
\end{tabular}

Not: (wLR) ve (wSR) Wald test istatistik değerleridir. Wald Testinde boş hipotez uzun ve kısa dönem simetri varsayımı üzerine kurulur. *, ** ve *** sırasiyla boş hipotezin $\% 1, \% 5$ ve $\% 10$ önem derecesinde reddedildiğini göstermektedir. Parantez içindeki değerler olasılıkları göstermektedir.

Tablo 5. Model 2 için Kısa ve Uzun Dönem Asimetriye Ilişkin Wald Testi Sonuclar

\begin{tabular}{lll}
\hline Değişkenler & Uzun Dönem Asimetri $\left(\mathrm{w}_{\mathrm{LR}}\right)$ & Kisa Dönem Asimetri (wSR \\
\hline Rer & $2.24^{* *}(0.02)$ & $-1.84^{* *}(0.04)$ \\
Sue & $1.03(0.30)$ & $0.15(0.25)$ \\
Growth & $2.04^{* *}(0.04)$ & $4.96^{*}(0.00)$ \\
Tot & $1.85^{* * *}(0.06)$ & $-3.02^{*}(0.00)$ \\
\hline
\end{tabular}

Not: (WLR) ve (wSR) Wald test istatistik değerleridir. Wald Testinde boş hipotez uzun ve kısa dönem simetri varsayımı üzerine kurulur. $*$, ** ve *** sırasıyla boş hipotezin $\% 1, \% 5$ ve \%10 önem derecesinde reddedildiğini göstermektedir. Parantez içindeki değerler olasilıkları göstermektedir.

Wald Testinde boş hipotez açıklayıcı değişkenlerde meydana gelen negatif ve pozitif şokların kısa ve uzun dönemde simetrik etkiler meydana getirdiğini varsayarken, alternatif hipotez etkilerin asimetrik olduğunu varsayar. Buna göre, Tablo 4'teki Wald istatistik değerleri incelendiğinde, Model 1'de yer alan tüm açıklayıcı değişenler için hem kısa hem de uzun dönemde boş hipotezin reddedildiği görülmektedir. Buna göre, Model 1 için seçilen açıllayıcı değişkenlerde meydana gelen pozitif ve negatif şokların ihracat üzerindeki kısa ve uzun dönemli etkileri simetrik ve doğrusal değildir.

Tablo 5, Model 2 için yapılan kısa ve uzun dönem asimetri test sonuçlarını göstermektedir. Tablo 5’e göre sanayi üretim endeksi dışındaki tüm değişkenlerin için simetriyi varsayan boş hipotez hem kısa hem de uzun dönem için reddedilmiştir. Buna göre, sanayi üretim endeksi dışındaki değişkenlerin pozitif ve negatif bileşenlerinin dış ticaret dengesi üzerinde asimetrik etki meydana getirdiği anlaşılmaktadır. Sanayi üretim endeksi ise dış ticaret dengesinin kısa ve uzun dönemde simetrik belirleyicisidir.

Simetrik ve doğrusal ilişkilerde pozitif ve negatif şokların bağımlı değişken üzerinde birbirinin tersi ve eşit sonuçlar üretmesi beklenirken, asimetrik ve doğrusal olmayan ilişkilerde pozitif ve negatif şoklar bağımlı değişken üzerinde aynı yönlü ve eşit olmayan etkiler meydana getirebilmektedir. Buna göre, simetrik ilişkilerde, açıklayıcı değişkende meydana gelen bir birim pozitif şok, bağımlı değişkende artışa neden olduysa, bir birim negatif şokun bağımlı değişkende aynı ölçüde azalışa neden olması beklenir. Asimetrik ilişkilerde ise, bir birim pozitif ve negatif şok bağımlı değişkeni aynı yönde etkileyebileceği gibi farklı yönlerde ve farklı ölçüler de de etkileyebilir (Utkulu ve Ekinci, 2015, s.11). Pozitif ve negatif şokların bağımlı değişken üzerinde meydana getirecekleri asimetrik etkinin yönü NARDL tahmin sonuçları ve asimetrik dinamik çarpan fonksiyonları üzerinden değerlendirilebilmektedir.

\section{NARDL Tahmin Sonuçları}

Tablo 6 ve 7, Eşitlik (5) ve (6)'ya göre kurulan NARDL modellerine ilişkin tahmin sonuçlanını göstermektedir. Seçilen NARDL spesifikasyonlarında optimal gecikme uzunluğu, genelden özele yaklaşımı ile tespit edilmiştir. Model çözümlerine bağımlı ve bağımsız değişkenler için 12 gecikme (max $\mathrm{p}=\max$ $\mathrm{q}=12$ ) ile başlanmıs ve anlamsız gecikmeler modelden dışlanarak optimal NARDL spesifikasyonu belirlenmiştir. Pesaran and Shin (1998)'e göre ARDL tabanlı yaklaşımlarda doğru gecikme sırasının belirlenmesi otokorelasyon ve endojenite sorunlarını eşanlı olarak ortadan kaldırmaktadır. Modellere ait tanısal test sonuçları, otokorelasyon ve değişen varsans problemlerinin olmadığını güçlü bir şekilde ortaya 


\section{GÜLER}

Reel Döviz Kuru Şoklarının İhracat ve Dış Ticaret Dengesi Üzerindeki Asimetrik Etkileri: Türkiye Için NARDL Yaklaşımından Kanıtlar

koymaktadır. Modellerin açıklayıcılığına ve anlamlılı̆ına dair istatistikler de oldukça tatmin edicidir. Bu sonuçlar NARDL spesifikasyonlanının doğru tanımlandığını göstermektedir.

Tablo 6, ihracatın asimetrik belirleyicilerinde meydana gelen pozitif ve negatif şokların kısa ve uzun dönemli katsayı tahminlerini göstermektedir. Öncelikle, reel efektif döviz kurunda meydana gelen pozitif ve negatif şoklarla ilişkili uzun dönem elastikiyet katsayılarının (LRex+ ve LRex-) sırasıly \%1 ve \%5 düzeyinde istatistiksel olarak anlamlı olduğu görülmektedir. Buna göre, TL'de meydana gelen reel değer kayıpları (negatif şoklar) ve reel değer kazançları (pozitif şoklar) uzun dönemde ihracat üzerinde anlamlı asimetrik etkiler meydana getirmektedir ${ }^{6}$. Katsayıların işaretlerine bakıldığında, reel efektif kurdaki pozitif şokların (TL'nin reel değer kazancı) ihracatı olumsuz yönde etkilediği, negatif şokların (TL'nin reel değer kaybı) ise ihracatı olumlu yönde etkilediği anlaşılmaktadır. Nitekim TL'deki değer kazançlarını temsil eden $($ LRex + ) ve TL'deki reel değer kayıplarını temsil eden (LRex-) uzun dönem elastikiyet katsayılarının her ikisi birden negatif işaretlidir? Bununla birlikte, reel döviz kurundaki pozitif şoklara ilişkin uzun dönem elastikiyet katsayısının (LRex+) değeri -0.52'dir. Buna göre, uzun dönemde reel döviz kurlarında meydana gelen \%10’luk bir artış, ihracatın \% 5.2 oranında azalması yönünde etki etmektedir. Diğer taraftan, reel döviz kurunda meydana gelen negatif şoklara ilişkin uzun dönem elastikiyet katsayıs1 (LRex-) -0.45 olarak hesaplanmıştır. Buna göre, reel döviz kurunda meydana gelen \%10’luk azalma ihracatı yaklaşık \% 4.5 oranında arttırmaktadır. Kısa dönemde pozitif ve negatif reel döviz kuru şoklarının ihracat üzerindeki etkilerine bakıldığında da benzer sonuçlar göze çarpmaktadır. Buna göre, kısa dönemde TL'nin \%10 değer kazancı ihracatı yaklaşık \%5.5 oranında azaltırken, TL'nin \%10 değer kaybı ihracatı \%4.8 oranında arttırmaktadır. Kısa ve uzun dönem elastikiyet katsayılarına birlikte değerlendirildiğinde, ele alınan dönemde TL'nin değer kazançlarının ihracat üzerindeki etkisinin değer kayıplarına nazaran biraz daha fazla olduğu dikkati çekmektedir. Bu bulgu Ayhan (2019)'un sonuçları ile benzerlik göstermektedir.

Tablo 6. İbracat Modeline Illiskin NARDL Tabmin Sonuclar

\begin{tabular}{|c|c|c|c|c|c|c|c|}
\hline \multicolumn{4}{|c|}{ Kısa Dönem Asimetrik Etkiler } & \multicolumn{4}{|c|}{ Uzun Dönem Asimetrik Etkiler } \\
\hline Değişken & Katsayn & t-ist. & Olasilhk & Değiskeen & Katsayn & t-ist. & Olasilik \\
\hline Sabit & $7.61 *$ & 10.44 & 0.00 & $\mathrm{LRex}^{+}$ & -0.52 & -2.70 & 0.0087 \\
\hline Trend & -0.02 & -3.84 & 0.00 & $\mathrm{LRex}^{-}$ & -0.45 & -1.88 & 0.0639 \\
\hline Exp t-1 & -1.06 & -10.51 & 0.000 & $\operatorname{LImp}^{+}$ & 0.64 & 5.21 & 0.0000 \\
\hline $\operatorname{Rex}^{+}-1$ & -0.55 & -2.64 & 0.010 & LImp $^{-}$ & 0.17 & 1.33 & 0.1885 \\
\hline $\operatorname{Rex}^{-}$ & -0.48 & -1.91 & 0.061 & LGrowth $\mathrm{EU}^{+}$ & 0.03 & 1.11 & 0.2715 \\
\hline $\operatorname{Imp}{ }^{+}$ & 0.68 & 5.08 & 0.000 & LGrowth $\mathrm{EU}^{-}$ & 0.09 & -1.97 & 0.0531 \\
\hline $\operatorname{Imp}^{-} t-1$ & 0.19 & 1.33 & 0.187 & & & & \\
\hline Growth $_{\mathrm{EU}^{+}}{ }_{\mathrm{t}-1}$ & 0.04 & 1.10 & 0.277 & & & & \\
\hline Growth $_{\mathrm{EU}^{-}} \mathrm{t}-1$ & -0.10 & -1.90 & 0.062 & & & & \\
\hline$\Delta \operatorname{Rex}^{+}$ & 0.13 & 0.33 & 0.743 & & & & \\
\hline$\Delta \operatorname{Imp}^{-}$ & 0.78 & 8.13 & 0.000 & & & & \\
\hline$\Delta \operatorname{Imp}^{-}{ }_{\mathrm{t}-1}$ & 0.22 & 1.77 & 0.082 & & & & \\
\hline$\Delta$ Growth $_{\mathrm{EU}}{ }^{+}$ & 0.66 & 1.05 & 0.299 & & & & \\
\hline$\Delta$ Growth $_{\mathrm{EU}^{+}} \mathrm{t}-1$ & -0.85 & -1.42 & 0.160 & & & & \\
\hline$\Delta$ GrowtheU $^{-}$ & 0.02 & 2.70 & 0.009 & & & & \\
\hline$\Delta$ Growth $_{\mathrm{EU}^{-}} \mathrm{t}-1$ & 0.13 & 2.35 & 0.022 & & & & \\
\hline $\begin{array}{l}\Delta \text { Growth }_{\mathrm{EU}^{-} \mathrm{t}-2} \\
\mathrm{ec}(-1)^{*}\end{array}$ & 0.13 & 2.32 & 0.024 & & & & \\
\hline \multirow{4}{*}{\multicolumn{2}{|c|}{$\begin{array}{l}\text { Düzeltilmis } \mathrm{R}^{2} \\
\text { F ist. } \\
\text { Breusch-Godfrey LM Test } \\
\text { ARCH Test }\end{array}$}} & & 0.83 & & & & \\
\hline & & & $21.27 *$ ( & & & & \\
\hline & & & $1.16 \quad($ & & & & \\
\hline & & & 0.03 & & & & \\
\hline
\end{tabular}

$\left(\mathrm{LImp}^{+}\right)$ve ( $\left.\mathrm{LImp}^{-}\right)$ise hammadde ve ara malı ithalatında meydana gelen pozitif ve negatif şoklarla ilişkili uzun dönem elastikiyet katsayılarını göstermektedir. Katsayıların istatistiksel anlamlılık düzeylerine bakıldığında, yalnızca pozitif şoklara ilişkin katsayının \%1 seviyesinde anlamlı olduğu görülmektedir. Pozitif $\left(\mathrm{LImp}^{+}\right)$ve negatif şoklara $\left(\mathrm{LImp}^{-}\right)$ilişkin katsayılar sırasıyla 0.64 ve 0.17 olarak hesaplanmıştır.

${ }^{6}$ Daha öncede ifade edildiği gibi çalısmada kullanılan reel efektif kurların hesaplanmasında dolaylı kotasyon yöntemi kullanılmıştır. Buna göre reel kurun yükselmesi TL'nin değer kazancı reel kurun düşmesi ise TL'nin değer kaybetmesi anlamına gelmektedir.

${ }^{7}$ NRDL yaklaşımında negatif şoklara ait katsayının negatif işaretli olması regresörün negatif şokları temsil eden bileşeninin bağımlı değişken ile ters yönlü etkileşim içinde olduğunu göstermektedir. Bu durumda katsayının negatif bulunması, reel döviz kurundaki azalmanın (TL'nin değer kaybı) ihracat üzerinde artış yönlü bir etki meydana getirdiği şeklinde yorumlanmaktadır. 
Buna göre, hammadde ve ara malı ithalatında meydana gelen \%10'luk pozitif şokun uzun dönemde ihracatı \%6.4 oranında arttırdığı anlaşılmaktadır. Diğer taraftan, ithalatta meydana gelen \%10'luk negatif şok ise ihracatı \%1.7 oranında azaltmaktadır. Ancak bu etki istatistiksel olarak anlamsızdır. Kısa dönem katsayıları incelendiğinde ise yine ithalatta meydana gelen pozitif şokların ihracatı anlamlı bir şekilde arttırdığ1, negatif şokların etkisinin ise istatistiksel olarak anlamsız olduğu görülmektedir. Buna göre, kısa dönem için cari dönemde ithalatta meydana gelen $\% 10$ 'luk pozitif şok ihracatı yaklaşık $\% 6.8$ oranında arttırrrken, ithalatta önceki dönem meydana gelen \%10’luk negatif şok cari dönemde ihracat1 \%1.9 oranında azaltmaktadır.

Son olarak, Avrupa Birliği büyüme oranında meydana gelen pozitif ve negatif şokların ihracat üzerinde meydana getirdiği uzun dönem asimetrik etkilere ilişkin hesaplanan elastikiyet katsayılarının (LGrowth $\mathrm{EU}^{+}$ve LGrowth $\mathrm{EU}^{-}$) nispeten oldukça küçük değerler aldığı görülmektedir. Ayrıca, yalnızca negatif şoklara ilişkin katsayı istatistiksel olarak anlamlıdır. Buna göre, AB büyüme oranında meydana $\% 10 ’$ luk bir azalma uzun dönemde ihracatı yaklassık \%1 oranında düşürmektedir. Kısa dönem sonuçlarına bakıldığında da benzer bir tablo ile karşılaşılmaktadır. Nitekim, kısa dönemde pozitif şoklara ilişskin katsayıların anlamsız, negatif şoklara ilişkin katsayıların ise genellikle anlamlı oldukları görülmektedir. Şüphesiz AB'nin büyüme oranında meydana gelen pozitif ve negatif şokların ihracat üzerindeki etkilerinin nispeten önemsiz ve kısmen anlamsız bulunmasının bir nedeni toplam ihracatın yalnızca bir bölümünün AB ile yapilıyor olmasından ileri gelmektedir. Nitekim, çalışmada kullanılan ihracat rakamları, AB ile yapılan ihracatı değil tüm ihracatı kapsamaktadır.

Tablo 7. Dış Ticaret Dengesi Modeline Illiskkin NARDL Tabmin Sonuclar

\begin{tabular}{|c|c|c|c|c|c|c|c|}
\hline \multicolumn{4}{|c|}{ Kısa Dönem Asimetrik Etkiler } & \multicolumn{4}{|c|}{ Uzun Dönem Asimetrik Etkiler } \\
\hline Değiskeen & Katsayı & $t$-ist. & Olasilik & Değişkeen & Katsayı & t-ist. & Olasulik \\
\hline $\mathrm{C}$ & 0.38 & 4.44 & 0.00 & $\operatorname{LRex}^{+}$ & -0.45 & -1.35 & 0.06 \\
\hline $\mathrm{TB}_{\mathrm{t}-1}$ & -0.67 & -5.26 & 0.00 & LRex $^{-}$ & -1.05 & -6.09 & 0.00 \\
\hline $\operatorname{Rex}^{+}{ }_{t-1}$ & -0.30 & -1.34 & 0.19 & $\mathrm{LSue}^{+}$ & -0.72 & -4.41 & 0.00 \\
\hline $\operatorname{Rex}^{-}$ & -0.71 & -4.55 & 0.00 & LSue $^{-}$ & -0.78 & -3.49 & 0.00 \\
\hline Sue $_{t-1}^{-}$ & -0.52 & -4.07 & 0.00 & LGrowth $_{\mathrm{EU}^{+}}{ }^{+}$ & 0.04 & 1.72 & 0.09 \\
\hline $\mathrm{Sue}^{+} \mathrm{t}-1$ & -0.48 & -4.51 & 0.00 & LGrowth $_{\mathrm{EU}^{-}}$ & 0.03 & 5.56 & 0.00 \\
\hline Growth $_{\mathrm{EU}}{ }^{+} \mathrm{t}-1$ & 0.03 & 1.17 & 0.25 & Ltot+ & 0.63 & 5.69 & 0.00 \\
\hline Growth $_{\mathrm{EU}^{-} \mathrm{t}-1}$ & 0.02 & 4.96 & 0.00 & Ltot & 0.84 & 1.73 & 0.08 \\
\hline $\operatorname{Tot}^{+}{ }_{t-1}$ & 1.87 & 3.80 & 0.86 & & & & \\
\hline Tot ${ }_{t-1}$ & 0.96 & 1.53 & 0.13 & & & & \\
\hline$\Delta \mathrm{TB}_{\mathrm{t}-1}$ & -0.13 & -1.13 & 0.26 & & & & \\
\hline$\Delta \operatorname{Rex}^{+}$ & 0.46 & 1.24 & 0.22 & & & & \\
\hline$\Delta \operatorname{Rex}^{+}{ }_{t-1}$ & 0.49 & 1.39 & 0.17 & & & & \\
\hline$\Delta \mathrm{Sue}^{-}$ & 0.01 & 0.13 & 0.90 & & & & \\
\hline$\Delta \mathrm{Sue}^{+}$ & -0.15 & -1.19 & 0.24 & & & & \\
\hline$\Delta \mathrm{Sue}_{\mathrm{t}-1}^{+}$ & 0.29 & 2.72 & 0.01 & & & & \\
\hline$\Delta$ Growth $_{\mathrm{EU}}+$ & 0.83 & 1.51 & 0.14 & & & & \\
\hline$\Delta$ GrowtheU $_{\mathrm{E}-1}{ }^{+}$ & -0.75 & -1.51 & 0.14 & & & & \\
\hline$\Delta$ Growth $_{\mathrm{EU}}^{-}$ & 0.01 & 3.04 & 0.00 & & & & \\
\hline$\Delta \operatorname{Tot}^{+}$ & 2.09 & 2.48 & 0.02 & & & & \\
\hline$\Delta$ Tot & -0.99 & -0.95 & 0.35 & & & & \\
\hline$\Delta$ Tot $_{\mathrm{t}-1}$ & -1.23 & -1.40 & 0.17 & & & & \\
\hline $\mathrm{Ec}(-1)$ & -0.67 & -9.44 & 0.00 & & & & \\
\hline \multicolumn{2}{|l|}{ Düzeltilmi $\mathrm{R}^{2}$} & 0.83 & & & & & \\
\hline \multicolumn{2}{|c|}{ Fist.. } & 15.97 & & & & & \\
\hline \multicolumn{2}{|c|}{ Breusch-Godfrey LM Test } & 1.22 & & & & & \\
\hline \multicolumn{2}{|c|}{ ARCH Test } & 1.14 & & & & & \\
\hline
\end{tabular}

Not: "+" ve "-" üst simgeleri pozitif ve negatif kısmi toplamları gösterir, $\mathrm{L}^{+}$and $\mathrm{L}^{-}$ilgili değişkenin pozitif ve negatif değişiklikleriyle ilişkili tahmini uzun dönem katsayılarıdır, $\mathrm{L}^{+}=-\theta^{+} / p, L^{-}=-\theta^{-} / p$. Parantez içindeki sayılar olasılık değerleridir.

Tablo 7, diş ticaret dengesinin asimetrik ve doğrusal olmayan belirleyicilerine ilişkin tahmin sonuçlarını göstermektedir. İlk olarak, uzun dönem sonuçları incelendiğinde, reel döviz kurundaki pozitif ve negatif şoklara ait uzun dönem elastikiyet katsayılarının (LRex+ ve LRex-) anlamllık düzeylerinin sırasıyla $\% 10$ ve $\% 1$ olduğu görülmektedir. Buna göre, TL'de meydana gelen değer kazanç ve kayıpları uzun dönemde dış denge üzerinde anlamlı asimetrik etkiler meydana getirmektedir. Pozitif ve negatif şokları temsil eden uzun dönem elastikiyet katsayılarının her ikisinin birden negatif olması, TL'deki değer kazançlarının (LRex+) dış dengeyi kötüleştirdiği, TL'deki reel değer kayıplarının (LRex-) ise dış dengeyi 


\section{GÜLER}

iyileştirdiği anlamına gelmektedir. Ulaşılan bu sonuç Ayhan (2019), Barak ve Naimoğlu (2018), Kilıç, Özbek ve Çiftçi (2018)'nin bulguları ile tutarlıdır. Bununla birlikte, reel döviz kurundaki pozitif şoklara ilişkin uzun dönem elastikiyet katsayısının (LRex+) değeri -0.45 olarak hesaplanmıştır. Buna göre, uzun dönemde reel döviz kurlarında meydana gelen \%10’luk bir artış, dış dengenin \% 4.5 oranında kötüleşmesine neden olmaktadır. Buna karşın, reel döviz kurunda meydana gelen negatif şoklara ilişkin uzun dönem elastikiyet katsayısı (LRex-) -1.05 olarak hesaplanmıştır. Buna göre, reel döviz kurunda meydana gelen \%10’luk azalma dış dengenin yaklaşık \%10.5 oranında iyileşmesine yol açmaktadır. Kısa dönemde ise TL'nin t-1 dönemindeki \%10 değer kazancı cari dönemde dış dengeyi yaklaşı $\% 3$ oranında bozarken, TL'nin \%10 değer kaybı dış dengeyi \% 7 oranında iyileştirmektedir. Öte yandan, reel döviz kurundaki negatif şokları temsil eden elastikiyet katsayıları, pozitif şokları temsil eden katsayıların hem kısa hem de uzun dönemde hemen hemen iki katıdır. Bu durum, dış ticaret dengesinin TL'nin değer kayıplarına karşı iki kat daha duyarlı olduğunu göstermektedir. Bu sonuç, Arize, Malindretos ve Igwe (2017)'nin bulguları ile örtüşmektedir.

Modelin diğer açılayıcı değişkeni olan sanayi üretim endeksine ilişkin pozitif ve negatif şokların dış denge üzerindeki etkisini gösteren uzun dönem elastikiyet katsayılarının (LSue+) ve (LSue ${ }^{-}$) her ikisi de $\% 1$ seviyesinde istatistiksel olarak anlamlı bulunmuştur. Ayrıca, katsayıların her ikisi birden beklentiye uygun şekilde negatif işaretlidir. Sanayi üretim endeksinde meydana gelen pozitif şokların dış denge üzerindeki etkisini gösteren elastikiyet katsayısının (LImp ${ }^{+}$) değeri -0.72 olarak hesaplanmıştır. Buna göre, sanayi üretim endeksinde meydana gelen \%10'luk artış uzun dönemde diş dengenin \% 7.2 oranında kötüleşmesine neden olmaktadır. Diğer taraftan, negatif şoklarla ilişkili elastikiyet katsayısının hesaplanan değeri ise -0.78 'dir. Buna göre sanayi üretim endeksindeki $\% 10$ 'luk düşüş diş denge üzerinde $\% 7.8$ oranında iyileşme meydana getirmektedir. Kısa dönemde ise sanayi üretim endeksinde meydana gelen \%10’luk pozitif şok dış dengeyi \%5.2 oranında kötüleştirirken, \%10’luk negatif şok ise dış dengeyi \% 4.8 oranında iyileştirmektedir. Gerek kısa dönem gerekse uzun dönem elastikiyet katsayılarının nispi büyüklükleri değerlendirildiğinde, negatif şokların dış denge üzerindeki olumlu etkisinin, pozitif şokların neden olduğu olumsuz etkiye göre daha belirgin olduğu anlaşılmaktadır.

$\mathrm{AB}$ büyüme oranında meydana gelen pozitif ve negatif şoklara ilişkin uzun dönem elastikiyet katsayılarının değerleri ise ihracat modelinde olduğu gibi, nispeten düşük hesaplanmıştır. Bununla birlikte, uzun dönem elastikiyet katsayılarının (LGrowth $\mathrm{EU}^{+}$LGrowth $\mathrm{EU}^{-}$) her ikisi de $\% 10$ ve $\% 1$ seviyelerinde istatistiksel olarak anlamlıdır. Buna göre, $\mathrm{AB}$ ülkelerinin büyüme oranında meydana gelen $\% 10$ luk bir artış diş ticaret dengesinde \%0.4'lük bir iyileşme sağlarken, \%10’luk bir azalma uzun dönemde diş ticaret dengesinde yaklaşık \% 0.3'lük bir bozulmaya neden olmaktadır. Kısa dönem katsayıları incelendiğinde, pozitif şokları temsil eden katsayının anlamsız, negatif şokları temsil eden katsayının anlamlı olduğu görülmektedir.

Son olarak, diş ticaret hadlerinde meydana gelen pozitif ve negatif şokların uzun dönemde diş denge üzerindeki etkisini gösteren elastikiyet katsayılarının $\left(\operatorname{Ltot}^{+}\right.$ve Ltot $\left.{ }^{-}\right)$her ikisi birden beklentiye uygun şekilde pozitif işaretli ve sırasıyla \%1 ve \%10 seviyesinde istatistiksel olarak anlamlıdır. Buna göre, dış ticaret hadlerinde meydana gelen pozitif şoklar diş dengeyi iyileştirirken, dış ticaret hadlerinde meydana gelen negatif şoklar dış dengenin kötüleşmesine neden olmaktadır. Diğer taraftan, pozitif ve negatif şoklara ilişkin katsayıların birbirinden farklı olması, ticaret hadlerindeki artış ve azalışların dış denge üzerinde simetrik etkiler meydana getirmediğine işaret etmektedir. Dış ticaret hadlerindeki pozitif şoklara ilişkin elastikiyet katsayısının değeri 0.63 , negatif şoklara ilişkin elastikiyet katsayısının değeri ise 0.84 olarak hesaplanmıştır. Buna göre, dış ticaret hadlerinin $\% 10$ artması dış dengede $\% 6.3$ 'lük bir iyileşme sağlarken, $\% 10$ azalması ise dış dengede $\% 8$.4'lük bozulmaya neden olmaktadır.

\section{Asimetrik Dinamik Çarpan Fonksiyonları}

NARDL analizinin son aşamasında açıklayıcı değisskenlerde meydana gelen bir birimlik pozitif ve negatif şoka karşılık bağımlı değişkenin dinamik birikimli tepkilerini ve şokun ardından yeni uzun dönem dengesine dinamik ayarlanma patikasını gösteren çarpanlar hesaplanmaktadır. Aşağıldaki grafikler ihracat ve dış ticaret dengesinin bağımlı değişken olduğu modeller baz alınarak, her bir açıklayıcı değişken için hesaplanan asimetrik dinamik çarpanları göstermektedir. Grafiklerde yer alan siyah kesiksiz çizgi, bağımsız değişkenin açıklayıcı değişkenlerdeki pozitif şoklara verdiği dinamik birikimli tepkiyi gösterirken, siyah kesikli çizgi ise negatif şoklara verdiği birikimli tepkiyi temsil etmektedir. Kalın kesikli kırmızı çizgi ise asimetri eğrisidir, kısaca pozitif ve negatif şokların bağımlı değişken üzerindeki birikimli etkisini gösteren çarpanlar arasındaki farkı gösterir. Asimetri eğrisinin pozitif olması, pozitif şokların negatif şokların etkisini 
domine ettiği anlamına gelirken, asimetri eğrisinin negatif olması ise negatif şokların etkisinin pozitif şokların etkisini domine ettiği anlamına gelmektedir. Asimetri eğrisinin altından ve üstünden geçen ince kesikli kırmızı çizgi ise \%95 güven aralığını temsil etmektedir. Güven aralığı zamanın belli bir noktasında sıfır çizgisini içeriyorsa asimetrinin $\% 5$ düzeyinde istatistiksel olarak anlamlı olmadığı sonucuna varılır.

Grafik 1a. ihracatın reel döviz kurunda meydana gelen bir birimlik pozitif ve negatif bir şokun ardından yeni uzun dönem dengesine dinamik ayarlanma patikasını göstermektedir. Bu grafik, ihracatın reel döviz kurunda meydana gelen pozitif ve negatif şoklara hem kısa hem de uzun dönemde asimetrik ve doğrusal olmayan tepkiler gösterdiğini göz önüne sermektedir. Grafiğe göre, yaklaşık ilk iki aylık kısa dönemde hem pozitif (TL'nin reel değer kazancı) hem de negatif (TL'nin reel değer kaybı) reel döviz kuru şokları ihracatın artmasına neden olmaktadır. Grafik incelendiğinde, ihracatın özellikle pozitif reel kur şoklarına özellikle ilk 5 ay içinde doğrusal olmayan tepkiler verdiği görülmektedir. İhracatın reel döviz kurunda meydana gelen bir birimlik pozitif şoka tepkisi ilk iki ayllk dönemde birikimli olarak pozitif yönlü 0.15 birimdir. 2. aydan sonra ise ihracat pozitif kur şokuna ters yönde tepki vererek azalmaktadır. Buna göre, TL'nin değer kazançları ilk iki aylık dönemde ihracatta küçük bir artışa, sonrasında ise azalmaya neden olmaktadır. 3. aya gelindiğinde bir birimlik pozitif reel kur şoku karşısında ihracatın verdiği birikimli tepki -0.57 birime ulaşmaktadır. Sonraki aylarda ihracatın pozitif kur şokuna verdiği ters yönlü tepki devam etmekte ve birikimli olarak -0.53 birim olmaktadır. Reel döviz kurunda meydana gelen bir birimlik negatif şokun ihracat üzerindeki etkisi ise kısa ve uzun dönemde pozitiftir. Buna karşın, bu olumlu etki zaman içerisinde artarak kendini göstermektedir. Buna göre, yaklaşı1k iki ay içerisinde bir birimlik negatif reel kur şokuna karşı ihracat birikimli olarak 0.48 birim pozitif tepki vermektedir. Sonraki dönemlerde ise ihracatın pozitif reel kur şokuna verdiği tepki birikimli olarak 0.46 birim olmaktadır. Birikimli dinamik çarpanlar incelendiğinde ihracatın özellikle kısa dönemde hem pozitif hem de negatif kur şoklarına güçlü asimetrik tepkiler verdiği anlaşılmaktadır. Bununla birlikte, kısa dönemde negatif reel döviz kuru şokunun ihracat üzerindeki etkisi pozitif kur şokuna göre 3 kat daha baskındır. Daha uzun vadelerde pozitif reel kur şokunun ihracat üzerindeki olumsuz etkisi, negatif kur şokunun ihracat üzerindeki olumlu etkisini domine etmektedir. Reel kur şoklarını takiben ortaya çıkan dengesizlikler 12 ay içinde ortadan kalkmaktadır. Ancak, yeni uzun dönem dengesine tam uyum aşamalı bir şekilde gerçekleşmektedir.

İhracatın hammadde ve aramalı ithalatında meydana gelen bir birimlik şok sonrası yeni uzun dönem dengesine dinamik asimetrik ayarlanma süreci Grafik 1b'deki gibidir. Grafik 1b, ihracatın hammadde ve aramalı ithalatında meydana gelen pozitif ve negatif yönlü değişimlere kısa ve uzun dönemde anlamlı asimetrik tepkiler verdiğini doğrulamaktadır. Buna göre, ithalatta meydana gelen pozitif şoklar ihracatı arttırırken, negatif şoklar ise azaltmaktadır. Kısa dönemde ihracatın, ithalatta meydana gelen bir birim pozitif şoka gösterdiği reaksiyon ikinci aya ulaşıldığında birikimli olarak 0.67 birim iken, bir birim negatif şoka gösterdiği reaksiyon birikimli olarak 0.78 olmaktadır. İhracat ithalatta meydana gelen şoklara karşı ilk 5 ay hızlı bir ayarlanma göstermektedir. Yaklaşı 5 . ay sonrası dönemde ihracatın pozitif şoka verdiği tepki 0.64 , negatif şoka verdiği tepki ise -0.18 birim olmaktadır. Bu tabloya göre, ihracat, ithalatta meydana gelen artış ve azalışara karşı ne kısa ne uzun dönemde simetrik reaksiyon göstermemektedir. Bu bağlamda, kısa dönemde hammadde ve aramalı ithalatındaki azalmalar ihracatı önemli ölçüde olumsuz etkilerken, uzun dönemde bu olumsuzluğun \%50'den fazlası ortadan kalkmaktadır. Yine uzun dönemde hammadde ve ara malı ithalatındaki artışların ihracat üzerindeki olumlu etkisi, azalısların olumsuz etkisine göre 3 kat daha güçlüdür. Bu bulgu Sönmezler, Akduğan ve Gündüz (2017)'nin sonuçları ile örtüşmektedir.

Son olarak, Grafik 1c, ihracatın AB büyüme oranında meydana gelen bir birimlik pozitif ve negatif şok sonrası yeni uzun dönem dengesine ayarlanma modelini göstermektedir. Öncelikle Grafik 1c, ihracatın AB büyüme oranında meydana gelen pozitif ve negatif şoklara özellikle kısa dönemde güçlü asimetrik tepkiler verdiğini kanıtlamaktadır. Ancak, söz konusu asimetrik etki, ihracatın yeniden dengeye geliş sürecinin büyük bir kısmında istatistiksel olarak anlamsızdır. Asimetrik etkinin $\% 5$ seviyesinde istatistiksel anlamlılığı ihmal edildiğinde çok kısa dönemde $\mathrm{AB}$ büyüme oranında meydana gelen bir birim pozitif şok ihracatı $\% 0.45$ arttırırken, bir birimlik negatif şok ise \%0.68 oranında azaltmaktadır. Bununla birlikte grafik incelendiğinde, büyüme oranındaki şok sonrası ihracatın yeni uzun dönem dengesine ulaşma sürecinin nispeten daha kısa sürdüğü çıkarımı yapılabilmektedir. 


\section{GÜLER}

Reel Döviz Kuru Şoklarının İhracat ve Dış Ticaret Dengesi Üzerindeki Asimetrik Etkileri: Türkiye İçin NARDL Yaklaşımından Kanıtlar

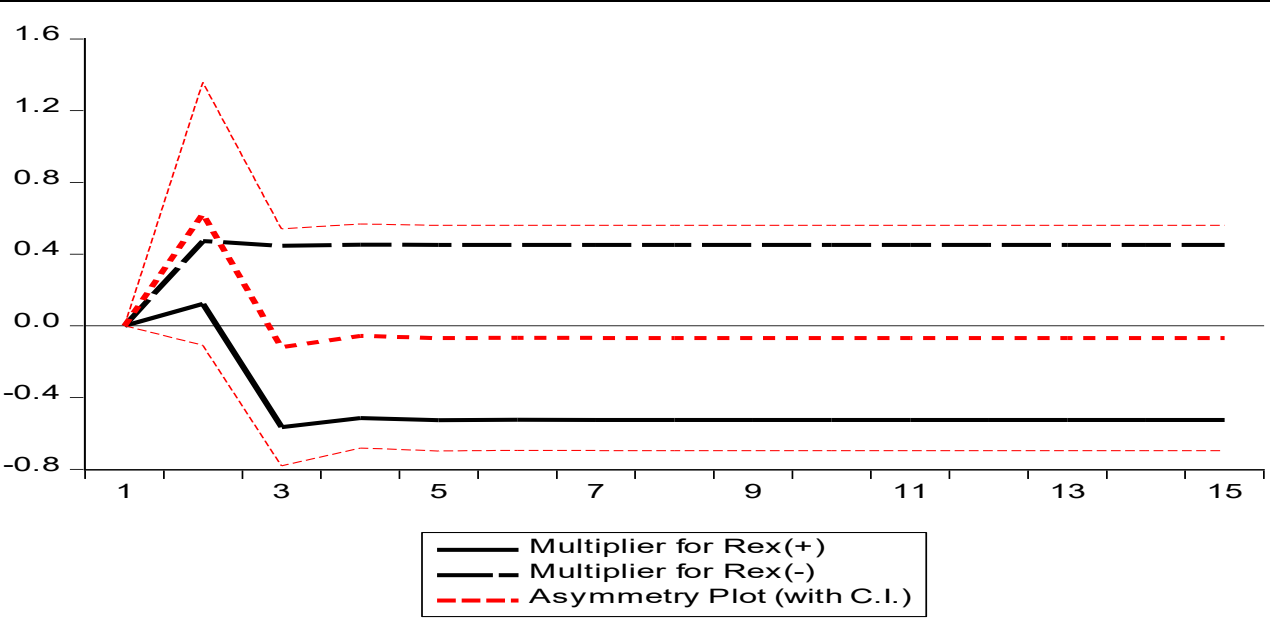

a) İbracat-Reel döviz kuru

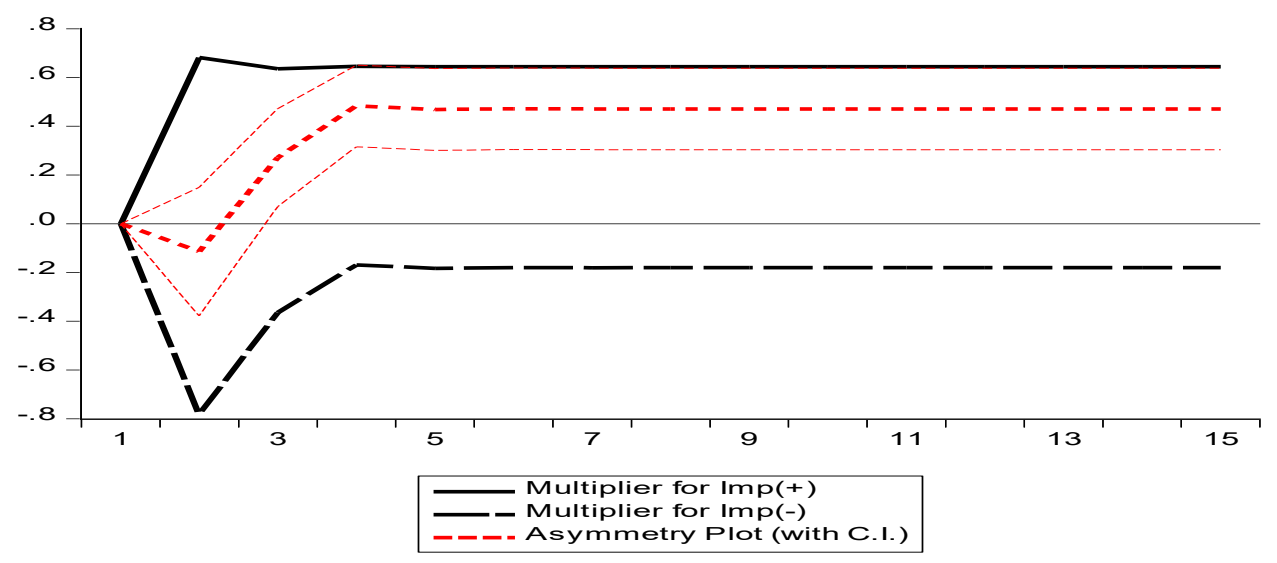

b) İbracat-Hammadde ve Aramal Ithalatı

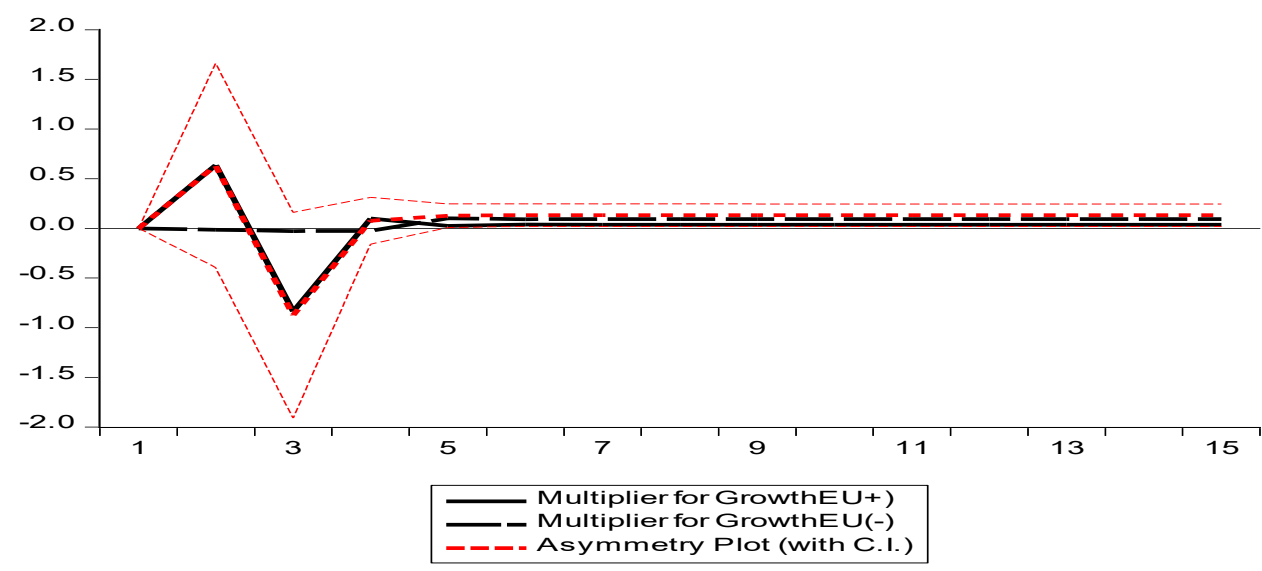

c) İbracat - AB Büyüme oran

Grafik 1. İhracat Modeli için Birikimli Asimetrik. Dinamik Çarpan Fonksiyonlar 


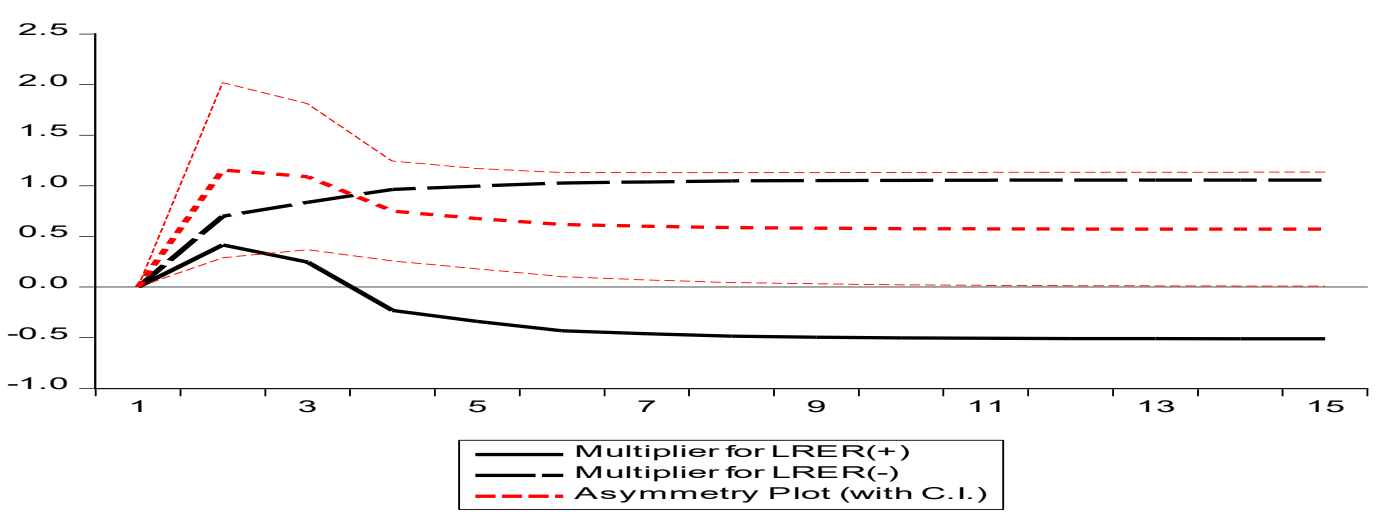

a) Dıș Ticaret Dengesi- Reel Döviz Kuru

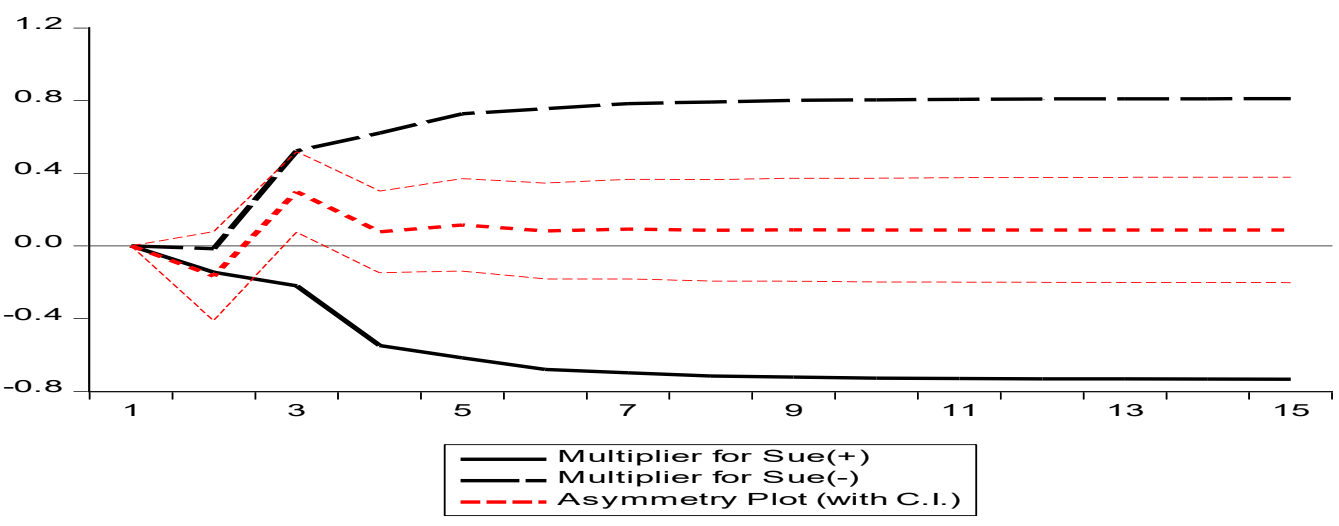

b) Dıș Ticaret Dengesi-Sanayi Üretim Endeksi

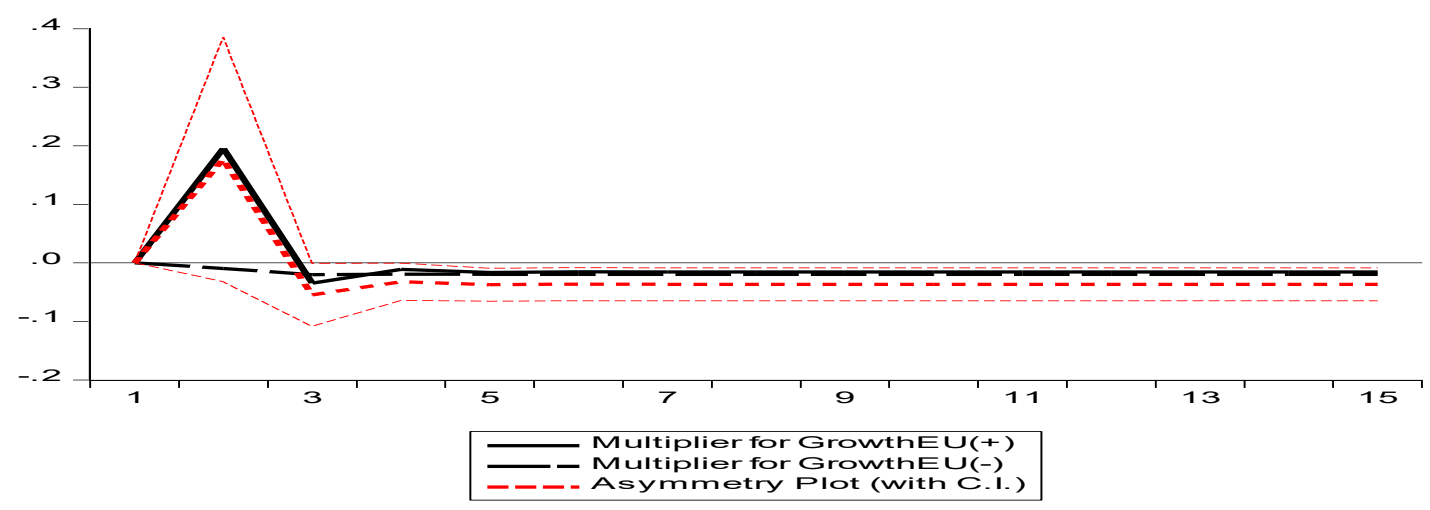

c) Dış Ticaret Dengesi- AB Büyüme Oranı

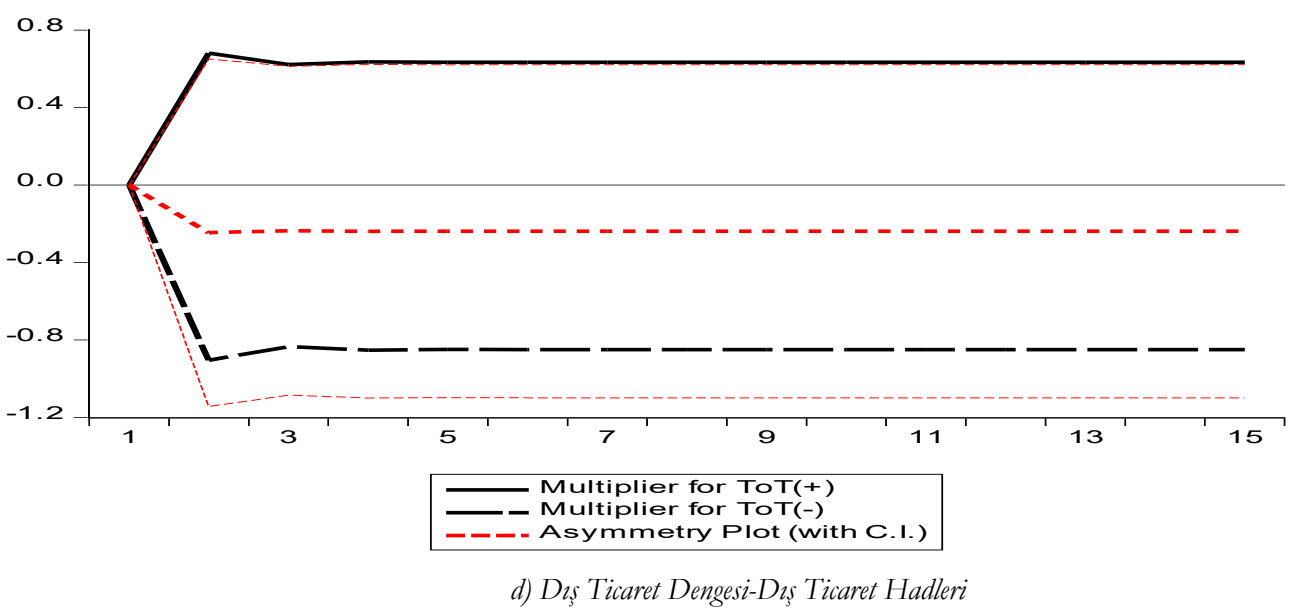

Grafik 2. Dış Ticaret Dengesi Modeli için Birikimli Asimetrik Dinamik Çarpan Fonksiyonları 


\section{GÜLER}

Grafik 2a reel döviz kurunda meydana gelen pozitif ve negatif şoklar karşısında dış ticaret dengesinin verdiği asimetrik tepkileri ve uzun dönem dengesine dinamik yakınsama sürecini göstermektedir. Grafiğe göre, diş ticaret dengesi pozitif reel döviz kuru şoklarına (TL’nin reel değer kazanci) ilk aylarda pozitif tepki vermektedir. Buna göre, TL’nin değer kazancının ilk üç aylık kısa dönemde dış ticaret dengesini iyileştirdiği söylenebilir. Ancak, söz konusu bu olumlu etki azalarak 4. ay itibari ile kaybolmakta ve dış ticaret dengesinin pozitif reel kur şokuna tepkisi negatife dönmektedir. Pozitif reel kur şokunun diş ticaret dengesi üzerinde meydana getirdiği olumsuz ise etki yaklaşık 7. aya kadar birikimli bir şekilde artmaktadır. Diğer bir deyişle, TL'nin değer kazancı diş ticaret dengesini önce olumlu yönde etkilemekte, daha sonra ise dengeyi kademeli bir şekilde bozmaktadır. 7. ay sonrası dönemde dış dengenin bir birim pozitif reel kur şokuna verdiği birikimli tepki -0.51 birim seviyesinde istikrara kavuşmaktadır. Diğer yandan, dış ticaret dengesinin negatif reel kur şoklarına (TL'nin reel değer kaybı) verdiği tepki nispeten daha istikrarlıdır. Negatif reel kur şoku, dış ticaret dengesini hem kısa hem de uzun dönemde iyileştirmektedir. Dış denge bir birim negatif kur şokunun ardından yaklaşı 5. aya kadar önce artan sonra ise azalan bir hızlı bir ayarlanma göstermektedir. Yeni uzun dönem dengesine ayarlanması ise yaklaşık bir yıl sürmektedir. Negatif kur şokunun diş denge üzerinde meydana getirdiği olumlu etki, yeni uzun dönem dengesine ulaşılana kadar birikimli olarak artış göstermektedir. Ayrıca, kısa ve uzun dönem asimetrilerin istatistiksel olarak anlamlı olduğu görülmektedir. Ayrıca, asimetri eğrisinin pozitif tarafta yer alması şoklar sonrası dış denge üzerinde ortaya çıkan pozitif etkinin negatif etkiye göre baskın olduğu anlamına gelmektedir. Buna göre, uzun dönemde negatif kur şoklarının (TL'nin reel değer kayıplarının) dış dengeyi iyileştirici etkisi daha fazladır.

Dış ticaret dengesinin sanayi üretim endeksinde meydana gelen bir birimlik şok sonrası yeni uzun dönem dengesine dinamik asimetrik ayarlanma süreci Grafik 2b'deki gibidir. Grafik 2b, diş dengenin sanayi üretim endeksinde meydana gelen pozitif ve negatif yönlü değissimlere kısa ve uzun dönemde ters yönlü birikimli tepkiler verdiğini göstermektedir. Buna göre, sanayi üretim endeksinde meydana gelen pozitif şokun dış denge üzerindeki olumsuz etkisi kademeli bir şekilde artarak zamana yayılmaktadır. Diğer taraftan, sanayi üretim endeksinde meydana gelen negatif bir şoka karşıllık dış denge pozitif bir reaksiyon göstermekte ve nispeten daha hızlı bir ayarlanma göstermektedir.

Grafik 2c, dış dengenin $A B$ büyüme oranında meydana gelen bir birimlik pozitif ve negatif şok sonrası yeni uzun dönem dengesine ayarlanma modelini göstermektedir. Dinamik çarpanlar, AB büyüme oranındaki artış ve azalışların dış denge üzerindeki etkilerinin simetrik olmadığını açık bir şekilde göstermektedir. Buna göre, büyüme oranı yükseldiğinde kısa dönemde dış dengede belirgin olumlu bir etki meydana gelirken, büyüme oranı düştüğünde dış denge üzerinde belirgin bir olumsuzluk meydana gelmemektedir.

Son olarak Grafik 2d, dış ticaret hadlerinde meydana gelen birim pozitif ve negatif şok sonrası diş ticaret dengesinin yeni uzun dönem dengesine dinamik yakınsama sürecini göstermektedir. Grafiğe bakıldığında dış ticaret dengesinin pozitif ve negatif şoklara karşı kısa ve uzun dönemde farklı tepkiler verdiği anlaşılmaktadır. Nitekim, dış ticaret hadlerindeki negatif şokların dış denge üzerindeki olumsuz etkisi, pozitif şokların olumlu etkisine göre daha baskındır. Dinamik çarpana göre, bir birim pozitif şok sonrası dış denge üzerinde meydana gelen birikimli etki kısa dönemde (2. ay içinde) 0.68 birimdir. Diğer taraftan, bir birimlik negatif şoka verilen tepki 0.90 birim olmaktadır. Uzun dönemde ise diş dengenin pozitif ve negatif şoklara verdiği tepki istikrarlıdır. Buna göre, dış ticaret hadlerinde meydana gelen bir birimlik pozitif, şok uzun dönemde dış dengede birikimli olarak 0.64 birim etki meydana getirirken, negatif şok -0.85 birim etki meydana getirmektedir.

\section{Sonuç, Tartışma ve Öneriler}

Makroekonomik değişkenler arasındaki ilişkiler zaman içerisinde önemli yapısal değişikliklere maruz kalabilmektedir. Bu durum, bir değişkenin başka değişkende meydana gelen değişikliğe gösterdiği davranış kalıbını değiştirmektedir. Diğer taraftan, piyasa aksaklıkları, arz ve talebin esnekliklerinin farklı olması, belirli bir dönem için yapılmış sözleşmelerin varlığı vb. unsurlar, bir makroekonomik değişkenin başka bir değişkende meydana gelen aşağı ve yukarı yönlü şoklara gösterdiği reaksiyonun yönünü ve şiddeti birbirinden farklı kılabilmektedir. Asimetrik ilişkiler söz konusu olduğunda, doğaldır ki, değişkenler arasındaki ilişkinin doğrusal ve simetrik olduğunun varsayıldığı analizlere dayalı çıkarımlar, belli hedefleri gerçekleştirmeye yönelik politikalara yön ve şekil vermek için yeterince güvenilir ve sağlam olmayacaktır.

Bu bağlamda, çalışmada Türkiye'de reel döviz kurunda meydana gelen pozitif ve negatif şokların ihracat ve dış ticaret dengesi üzerinde meydana getirdiği kısa ve uzun dönemli asimetrik ve doğrusal olmayan ilişkiler 2013:01- 2020:05 dönemine ait aylı veriler kullanılarak NARDL yaklaşımı ile 
araştırılmıştır. Ayrıca, ihracat ve dış ticaret dengesini etkilediği düşünülen teori ile uyumlu makroekonomik değişkenler de modellere dahil edilerek söz konusu değişkenlerin ihracat ve diş ticaret dengesi üzerindeki potansiyel kısa ve uzun dönemli asimetrik etkileri araştırılmıştır.

Öncelikle asimetrik eş bütünleşme testleri ile modellerde yer alan değişkenler arasında uzun dönemde bir ilişki olup olmadığı sorgulanmış ve her iki modelde de boş hipotez güçlü bir şekilde reddedilerek değişkenlerin uzun dönemde ilişkili olduğu kanıtlanmıştır. Bu aşamadan sonra, açıklayıcı değisşkenlerin kısa ve uzun dönem etkilerine ilişkin asimetri testleri gerçekleştirilmiş ve söz konusu değişkenlerin büyük çoğunluğunda meydana gelen pozitif ve negatif şokların kısa ve uzun dönemde ihracat ve dış ticaret dengesi üzerindeki etkilerinin asimetrik olduğu anlaşılmıştır. Daha sonra ise söz konusu asimetrik etkilerin yönüne, kuvvetine ve tahmin dönemi boyunca nasıl değiştiğine ilişkin değerlendirmelerin yapılabilmesi için kısa ve uzun dönem asimetrik elastikiyet katsayıları ve pozitif ve negatif şoklara ilişkin asimetrik dinamik çarpan hesaplamaları yapılmışır.

İhracatın asimetrik belirleyicilerine ilişkin kurulan NARDL modeli için yapılan katsayı tahminlerinde reel döviz kurunda meydana gelen pozitif ve negatif şokların hem kısa hem de uzun dönemde ihracat üzerinde asimetrik etkiler meydana getirdiği doğrulanmıştır. Kısa ve uzun dönem için hesaplanan elastikiyet katsayılarının işaretlerine bakıldığında pozitif reel kur şoklarının (TL'nin reel değer kazancı) çok kısa dönemde ihracatı bir derece arttırdığı, ilerleyen dönemlerde ise ihracatı azalttığı; negatif reel kur şoklarının ise (TL'nin reel değer kaybı) ihracatı kademeli bir şekilde arttırdığı anlaşılmıştır. Kısa ve uzun dönem elastikiyet katsayıları ve asimetrik çarpan fonksiyonları incelendiğinde, pozitif reel kur şoklarının ihracat üzerinde meydana getirdiği olumsuz etkinin, negatif kur şoklarının meydana getirdiği olumlu etkiye göre biraz daha baskın olduğu sonucuna varılmıştır. Modelden elde edilen diğer ilginç bir sonuç ise ihracat ile hammadde ve aramalı ithalatı arasındaki asimetrik ilişkiye yöneliktir. Buna göre, ihracat, hammadde ve aramalı ithalatında meydana gelen pozitif şoklardan önemli ölçüde etkilenmektedir. İhracatın ithalata bağımlı olduğunu gösteren bu sonuç, ihracat artışının ithalat artışına bağlı olduğuna işaret etmektedir. Son olarak, yurt dışı gelir seviyesini temsilen analize dâhil edilen $\mathrm{AB}$ büyüme oranının da ihracatın asimetrik bir belirleyicisi olduğu ancak, etki düzeyinin nispeten sınırlı kaldığı tespit edilmiştir.

Dış ticaret dengesinin asimetrik belirleyicilerine ilişkin kurulan NARDL modeli için gerçekleștirilen tahminler, reel döviz kuru dış ticaret dengesi arasında da ters yönlü asimetrik bir ilişki olduğunu doğrulamaktadır. Buna göre, pozitif reel kur şoku (TL'nin değer kazancı) dış ticaret dengesinin önce iyileşmesine sonra ise bozulmasına yol açarken, negatif reel kur şoku (TL'nin reel değer kaybı) dış ticaret dengesinde kademeli bir iyileşmeye yol açmaktadır. Bununla birlikte, uzun dönemde TL'nin değer kaybının dış denge üzerinde meydana getirdiği olumlu etki, TL’nin değer kazancının neden olduğu olumsuz etkinin yaklaşık iki katıdır. Birikimli asimetrik çarpan fonksiyonları incelendiğinde, dış ticaret dengesinin negatif kur şokuna hemen uyum gösteremediği, kademeli bir şekilde tepki verdiği anlaşılmaktadır. Buna göre, negatif kur şokunu takiben dış ticaret dengesi üzerindeki olumlu etki 7. aya kadar birikimli şekilde artarken, sonrasında sabit bir hızda devam etmektedir. Tahminlerden elde edilen diğer sonuçlara göre, sanayi üretim endeksinde meydana gelen pozitif şoklar dış dengeyi olumsuz yönde etkilerken, negatif şoklar dış dengeyi iyileştirmektedir. Dış gelir ve talebi temsilen kullanılan $\mathrm{AB}$ büyüme oranının dış ticaret dengesi ile ilişkisi pozitif yönlü ancak, nispeten sınıllıdır. Son olarak, dış ticaret hadlerindeki düşüşlerin dış ticaret dengesi üzerinde meydana getirdiği bozulmanın derecesi, dış ticaret hadleri yükseldiğinde dış ticaret dengesinde ortaya çıkan iyileşme derecesinden daha fazladır.

Elde edilen bulgular birlikte değerlendirildiğinde, TL'de meydana gelen değer kayıplarının ihracatı arttırdığı ve dış ticaret dengesini iyileştirdiği, TL'nin değer kazançlarının ise ihracatı azalttığı ve dış ticaret dengesini bozduğu anlaşılmaktadır. Bununla birlikte, TL’nin değer kayıp ya da kazançlarının ihracat ve dış ticaret üzerinde meydana getirdiği etkiler birbirinin simetriği değildir. Buna göre, ihracat TL'nin reel değer kazançlarına daha fazla reaksiyon gösterirken, dış ticaret dengesi TL'nin reel değer kayıplarına iki kat daha fazla reaksiyon göstermektedir. Ayrıca, TL'nin reel değer kayıplarının dış ticaret dengesi üzerinde meydana getirdiği olumlu etki, ihracat üzerinde meydana getirdiği olumlu etkiden de daha fazladır. İhracatın ithalata bağımlılık derecesi göz önünde bulundurulduğunda, bu durumun TL'nin reel değer kayılarının ithalatı azaltmasından kaynaklı olabileceği düşünülmektedir. Diğer taraftan, dış ticaret dengesinin TL'deki değer kazançlarına karşı daha az, değer kayıplarına ise daha fazla tepki göstermesi, ihracatçıların reel kurdaki artışları fiyatlara aynı ölçüde yansıtamadıkları, bir kısmını kendi üzerlerinde tuttukları; reel kurdaki düşüşleri ise tamamen fiyatlara yansıttıkları şeklinde yorumlanmıştır. Bu durum, ihracat fiyatlarının, reel kur 
yükseldiğinde yukar1 yönlü kısmen kat1, reel kur düştüğünde ise aşağ1 yönlü esnek olduğunu ima etmektedir.

Sonuçlar değerlendirildiğinde, ihracatı ve dış ticaret dengesini gözeten reel kuru etkilemeye politikaların, TL'nin değer kayıp ve kazançlarının asimetrik etkilerini göz önünde bulundurması gerektiği açıktır. Ancak Türkiye'deki kronik dış ticaret açığının asıl müsebbibinin yoğun ithal girdi kullanımı olduğu göz önünde bulundurulduğunda, reel kuru etkilemeye yönelik politikaların sorunun çözümünde bir dereceye kadar etkili olabileceğini söylemek yanlış olmayacaktır. Bu gerekçe ile dış ticaret dengesini kalıcı olarak iyileştirmeyi hedefleyen politikaların öncelikle arz cephesindeki yapısal problemleri gidermeye odaklanması gerekmektedir. Böylelikle, ithal girdi kullanımını en aza indirecek, yüksek AR-GE'ye ve ileri teknolojiye dayalı katma değeri yüksek üretimin desteklenmesi ve teşvik edilmesi ile dış ticaret dengesinde daha kalıcı bir iyileşme mümkün olacaktır.

\section{Etik Beyan}

"Reel Döviz. Kuru Şoklarmm İhracat ve Dıș Ticaret Dengesi Üzerindeki Asimetrik Etkileri: Türkiye İçin NARDL Yaklaşımından Kanıtlar" başlıklı çalışmanın yazım sürecinde bilimsel kurallara, etik ve alıntı kurallarına uyulmuş; toplanan veriler üzerinde herhangi bir tahrifat yapılmamış ve bu çalışma herhangi başka bir akademik yayın ortamına değerlendirme için gönderilmemiştir. Bu araştırmada hazır veri seti kullanıldığı için etik kurul kararı zorunluluğu taşımamaktadır.

\section{Kaynakça}

Aktaş, C. (2010). Türkiye'de reel döviz kuru ile ihracat ve ithalat arasındaki ilişkinin VAR tekniğigle analizi. Uluslararası Yönetim İktisat ve İsletme Dergisi, 6(11), 123-140.

Arize, A. C., Malindretos, J. ve Igwe, E. U. (2017). Do exchange rate changes improve the trade balance: An asymmetric nonlinear cointegration approach. International Review of Economics \& Finance, 49, 313-326.

Ayhan, F. (2019). Türkiye ekonomisinde döviz kuru oynaklı̆̆ının dış ticaret üzerindeki etkisinin analizi. Business and Economics Research Journal, 10(3), 629-647.

Bahmani-Oskooee, M. ve Ratha, A. (2004). The J-curve: a literature review. Applied Economics, 36(13), 1377-1398.

Barak, D., ve Naimoğlu, M. (2018). Reel döviz kurunun dış ticaret üzerindeki etkisi: Kırılgan Beşli örneği. Ömer Halisdemir Üniversitesi İktisadi ve İdari Bilimler Fakültesi Dergisi, 11(2), 82-95.

Barışık, S., ve Demircioğlu, E. (2006). Türkiye'de döviz kuru rejimi, konvertibilete, ihracat-ithalat ilişkisi 1980-2001. Uluslararası Yönetim İktisat ve Issletme Dergisi, 2(3), 71-84.

Bickerdike, C. F. (1920). The instability of foreign exchanges," The Economic Journal, March.

Bussiere, M. (2013). Exchange rate pass-through to trade prices: The role of nonlinearities and asymmetries. Oxford Bulletin of Economics and Statistics. 75(5), 731-758.

Dornbusch, R. (1975). Exchange rates and fiscal policy in a popular model of international trade. The American Economic Review, 65(5), 859-871.

Eichengreen, B. ve Gupta, P. (2013). The real exchange rate and export growth: are services different?. MPRA Paper No. 43358.

Eryüzlü, H. ve Ekici, S. (2020). Konut fiyat endeksi ve reel döviz kuru ilişkisi: Türkiye örneği. İktisadi İdari ve Siyasal Arasttrmalar Dergisi, 5(12), 97-105.

Gül, E. ve Ekinci, A. (2006). Türkiye'de reel döviz kuru ile ihracat ve ithalat arasındaki nedensellik ilişkisi: 1990_ 2006. Dumlupinar Üniversitesi Sosyal Bilimler Dergisi, 16(1), 165-190.

Granger, C. W. ve Yoon, G. (2002). Hidden cointegration. University of California, Economics Working Paper, (2002-02).

Hepaktan, C. E., Çinar, S. ve Dündar, Ö. (2011). Türkiye'de uygulanan döviz kuru sistemlerinin diş ticaret ile ilişkisi. Akademik Arasturmalar ve Calssmalar Dergisi (AKAD), 3(5), 62-82.

Kilıç, R., Özbek, R. İ ve Çifçi, İ. (2018). Türkiye için j-eğrisi hipotezinin geçerliliğii: ARDL sınır testi yaklaşımı. International Journal of Disciplines Economics \& Administrative Sciences Studies 4, Issue:7, 112-128.

Magee, S. P. (1973). Currency contracts, pass-through, and devaluation. Brookings Papers on Economic Activity, 1973(1), 303-325.

Marshall, A. (1923). Money, credit \& commerce. Macmillan \& Company, London.

Metzler, L. (1948). The theory of international trade a survey of contemporary economics (Editör: Howard S. Ellis) The American Economic Association, Homewood, 210-214.

Lerner, A. P. (1944). Economics of control: Principles of welfare economics. Macmillan and Company Limited, New York.

Pesaran, M. H. ve Shin, Y. (1998). An autoregressive distributed-lag modeling approach to cointegration analysis. Econometric Society Monographs, 31, 371-413.

Pesaran, M. H., Shin, Y. ve Smith, R. J. (2001). Bounds testing approaches to the analysis of level relationships. Journal of Applied Econometrics, 16(3): 289-326.

Petek, A. ve Çelik, A. (2017). Türkiye'de enflasyon, döviz kuru, ihracat ve ithalat arasındaki ilişkinin ekonometrik analizi (1990-2015). Finans Politike \& Ekonomik Yorumlar, 54(626), 69-87.

Robinson, J. (1947). Beggar my neighbour policies. Essays in the Theory of Employment, Oxford; Basil Blackwell. 
Seyidoğlu, H. (2013). Uluslararası finans. Güzem Can Yayınları, İstanbul.

Shahzad, S. J. H., Nor, S. M., Ferrer, R. ve Hammoudeh, S. (2017). Asymmetric determinants of CDS spreads: US industry-level evidence through the NARDL approach. Economic Modelling, 60, 211-230.

Shin, Y., Yu, B. ve Greenwood-Nimmo, M. (2014). Modelling asymmetric cointegration and dynamic multipliers in a nonlinear ARDL framework. In Festschrift in honor of Peter Schmidt (pp.281-314). Springer, New York, NY.

Sönmezler, G., Akduğan, U. ve Gündüz, İ. O. (2017). Türkiye'de cari aç1k sorununun reel döviz kuru ve ihracatın ithalata bağımlılı̆̆ı açısından değerlendirilmesi. Maliye Finans Yazılar, (108), 105-122.

Şimşek, M. ve Kadılar, C. (2004). Türkiye'nin ithalat talebi fonksiyonunun sınır testi yaklaşımı ile eşbütünleşme analizi: 1970-2002. Doğus Üniversitesi Dergisi, Vol.5(1), 27-34.

Türkiye Cumhuriyet Merkez Bankası (2019). "2020 y1l para ve kur politikası”.

Türkiye Cumhuriyet Merkez Bankası (2020). "2021 y1l para ve kur Politikası”.

Utkulu, U. ve Ekinci, R. (2015). Uluslararası emtia fiyatlarindan iç fiyatlara asimetrik ve doğrusal olmayan fiyat geçişkenliği: Türkiye için NARDL modeli bulgular1, Discussion Paper, No. 2015/15, Turkish Economic Association, Ankara

Yamak, R. ve Korkmaz, A. (2005). Reel döviz kuru ve diş ticaret dengesi ilişkisi. Ekonometri ve İstatistike e-Dergisi, (2), 16-38.

Yılmaz, Ö. ve Kaya, V. (2007). İhracat, ithalat ve reel döviz kuru ilişkisi: Türkiye için bir VAR modeli. Iktisat Isletme ve Finans, 22(250), 69-84.

Zivot, E. ve Andrews, D. W. K. (1992). Further evidence on the great crash, the oil-price shock, and the unit-root hypothesis. Journal of Business \& Economic Statistics, 10, 251-270.

\section{EXTENDED ABSTRACT}

The purpose of this study is to analyze the asymmetric and non-linear short and long-term effects of the real effective exchange rate and selected macroeconomic indicators on exports and foreign trade balance with the nonlinear cointegration technique by using monthly data covering 2013:01-2020:05 period for Turkey. For this purpose, two NARDL models have been applied. The first model focuses on the dynamic relations of exports with the real exchange rate, imports of raw materials and intermediate goods, and foreign income while the second focuses on the relationship of foreign trade balance with the real exchange rate, domestic income, foreign income, and terms of trade. Considering the fact that both models are formed in logarithmic form, the obtained coefficients also express the flexibility.

Lots of studies dealing with the relationship between the real exchange rate and the balance of exports and foreign trade strikingly produce different results that are thought to be due to differences in country, period, or method. In this context, some studies conclude that the real exchange rate affects the foreign trade balance, while a substantial majority of the studies have concluded that there is neither a short nor long term relationship between the real exchange rate and foreign trade. This study analyzed the dynamics of short and long-term asymmetric relationships with potential determinants of export and foreign trade balance using the nonlinear auto-regressive distributed lag model (NARDL) developed by Shin et al. (2014). The NARDL approach is an extended version of the ARDL model extending to include short and long-term asymmetries. In the first stage of the analysis, asymmetric cointegration tests were conducted for each model. Following the determination of long-term relationships, short and long-term asymmetry tests were carried out. Finally, in order to determine the direction and strength of relations, coefficient estimates were made and asymmetric dynamic multiplier found out.

The findings of this paper are as follows.

i) The effects of TL's appreciation and depreciation on exports are asymmetrical. In the long term, exports react more to the appreciation of TL than to depreciation.

ii) Appreciation of TL cause exports to increase in the first two months and then to decrease. On the other hand, the depreciation of the TL causes the export to increase gradually.

iii) Besides, export asymmetrically related to intermediate goods imports and EU income level. While imports of intermediate goods are a strong asymmetric determinant of exports, the EU growth rate is a weak determinant.

iv) The relationship between foreign trade balance and appreciation and depreciation of TL are asymmetrical. The foreign trade balance shows two times more reaction to the depreciation of TL in both short and long terms than to appreciation. 


\section{GÜLER}

Reel Döviz Kuru Şoklarının İhracat ve Dış Ticaret Dengesi Üzerindeki Asimetrik Etkileri: Türkiye İçin NARDL Yaklaşımından Kanıtlar

v) Appreciation of TL affects the foreign trade balance positively in the first 3 months. However, in the following periods, real appreciation worsens the foreign trade balance. On the other hand, the depreciation of the TL causes a gradual improvement in the foreign trade balance.

vi) There is a negative symmetrical relationship between foreign trade balance and industrial production index. Besides, there is a positive asymmetric relationship between terms of trade and foreign trade balance. The reaction of the foreign trade balance against negative changes in the terms of trade is more than the reaction to positive changes in terms of trade. The EU growth rate is a weak determinator of the trade balance.

According to the findings, it is clear that the positive effect of real depreciation of TL on the foreign trade balance is more than the positive effect it has on exports. Considering the degree of dependency of exports on imports, it is thought that this situation may be due to reduced imports depending on the depreciation of TL. On the other hand, the fact that the foreign trade balance reacts less to appreciation TL and more to depreciation indicates that the exporters are not able to reflect the increases in real exchange rates to prices to the same extent, keeping some of the increases on themselves. On the other hand, they are more flexible to reflect the decreases in real exchange rates on prices.

This implies that export prices are partially inflexible to the upwards but flexible to the downwards, as the real exchange rate changes. As a result, the asymmetric effects of appreciation and depreciation of TL should be taken into consideration in policies looking out for the export and foreign trade balance. However, it is clear that policies aiming to permanently improve the foreign trade balance should focus primarily on resolving structural problems on the supply side. 